\title{
Bir Kimlik İnşası Olarak Ulus-Devlet Yurttaşlığı ve Yurttaşlık Kavramının Dönüşümü*
}

\section{The Transformation of Nation-State Citizenship and Citizenship as a Concept of Identity}

\author{
Mehmet GÜNGÖR**
}

\begin{abstract}
Öz: Bu çalışma ulus-devlet yurttaşlığından, küresel yurttaşlığa yurttaşlık olgusunun evrimi ile ilgilidir. Yurttaşlık olgusunun tarihsel süreç içerisinde nasıl tanımlandığı ve yurttaşlığı belirleyen ölçütlerin ne olduğu ve günümüze kadar uğradığı değişimler ele alınmıştır. Çalışma, yurttaşlığın tarihsel gelişimi içerisindeki kuramsal yaklaşımları, Dünya yurttaşı̆ı̆ı ile küresel yurttaşlık arasındaki farkları ele alarak, ulus-devletin yapısal ve niteliksel özellikleri ve ulus-devlet yurttaşlığının öncülleri olan ulus, ulusçuluk kavramları etrafında ele alınmıştır. Bununla birlikte ulus-devlet yurttaşlığından küresel yurttaşlığa geçisin ekonomik, sosyal ve kültürel ilişkileri ve küresel yurttaşlık projesinin görünümleri ortaya konulmuştur. Ulus-devlet yurttaşlığı küresel yurttaşlık projesi adı altında mikro- ulusçuluğun, etnik canlanmanın hızla arttığı, uluslararasıgüçlerin mazlum uluslar üzerindeki baskılarının yoğunlaştı̆̆ı yeni bir yüzyıl yaşanmaktadır. Ancak her şeye rağmen bu yüzyıl yine de ulus-devletlerin varlığının bir kez daha anlam kazandığı yüzyıl olacaktır.

Anahtar Kelimeler: Yurttaşl1k, ulus-devlet, küreselleşme
\end{abstract}

\begin{abstract}
This study is about the evolution of the citizenship concept starting from the nation-state citizenship to global citizenship. In the study issues like the ways how the citizenship concept has been defined in the historical span, what the measures that determine the citizenship are, the changes that the concept has been exposed to up to now, are discussed. This study discusses the struggle of the Turkish people during their transition from villainage to vassalage and then to citizenship and the effects of the global citizenship project on national citizenship in the context of the effects of globalism in the 21st century. The study considers the theoretical approaches during the historical process of the citizenship and the differences between the world citizenship and global citizenship, and they are discussed in the context of structural and factual features of nation-state and the concepts of nation and nationalism, which are the early steps of nation-state citizenship. Moreover, the economical, social and cultural consequences of the transition from nation-state citizenship to global citizenship and the outlook of global citizenship project are stated. We live in a new century in which micro-nationalism and ethnic awakening is increasing rapidly under the name of nation-state citizenship global citizenship project, and the compulsions of the international powers over inoffensive countries are becoming more intense day by day. However, this century will be a century in which the presence of nation states is appreciated once more.
\end{abstract}

Keywords: Citizenship, nation-state, globalization

\section{Giriş}

Yurttaşlık olgusu, bireyin aidiyet duygusu ile bağlı olduğu devletinin tarihsel süreç içerisinde yaşanılan sosyal, siyasal ve ekonomik değişim ve dönüşümle ilgilidir. Bu çalışmada yurttaşlık olgusunun tarihsel süreç içerisinde nasıl tanımlandığı ve yurttaşlığı belirleyen ölçütlerin ne olduğu ve günümüze kadar uğradığı değişimler ele alınmıştır. Bu bağlamda Türkiye Cumhuriyeti yurttaşlı̆̆ının bu gün geldiği nokta, küreselleşme sürecinin ulus-devlet üzerinde yarattığı sosyal, siyasal, ekonomik ve kültürel etkilerle irdelenmiştir. Yurttaşlık kavramı, sosyal ve siyasal

\footnotetext{
*Bu çalışma “Ulus-Devlet Yurttaşlığından Küresel Yurttaşlığa Türkiye'de Yurttaşlık Olgusu” başlıklı doktora tezinden üretilmiştir.

**Yrd. Doç. Dr., Mersin Üniversitesi, Eğitim Fakültesi, Mersin-Türkiye, e-posta: megungor06@ hotmail.com
} 
hakların edinildiği sosyolojik bir olgu-süreç olup, toplumsal kurum olan eğitiminve dolayısıyla da temel toplumsal koşullarla eğitim arasındaki etkileşimi de inceleyen sosyolojisinin konularından birini oluşturmaktadır. Ulusal eğitim modern ulus devletlerin temel bir mekanizmasıdır. Devletin politik bir kurum olarak varlığını ulusal kültürle eşitleyerek ulus devletlerin üzerine kurulduğu ilkeleri meşrulaştırmaktadır (Avdela, 2000). Ulus devletin eğitim kurumları olarak okullar aynı zamanda ulusal özellikleri ya da üstünlükleri, farklılıkları belirleyen karakteristikleri geliştiren ve bunları yeniden üreten mekânlar olarak da toplumun önemli kurumları olarak görülebilirler. Çünkü eğitim sürecinde genellikle belirli bir dil, lehçe, mezhep öne çıkarılmakta, ulusal kimliğin ülkesel boyutu vurgulanmakta ve kökenin ortak mitleri ile tarihsel anıları ulusal üstünlügü vb. desteklenmektedir (Dragones ve Boran, 2000).

Böylece, bir toplumda var olan egemen, siyasal, ekonomik, toplumsal ilişkiler düzenini yeniden üreterek meşrulaştırmaktadır. Bunu sağlayan düşünce, söylem ve pratikler bütünü olarak ideoloji, eğitim süreci boyunca ahlaki bir temelde bireylere benimsettirilmekte, dolayısıyla çocukluk çağından itibaren yurttaşlara, zorla değil rıza temelinde, var olan bir düzene itaat etmeleri ve sadakat göstermeleri sağlanabilmektedir (Parlak, 2005).

Yurttaşlık, genel bir tanımlamayla bir siyasal topluluğa aidiyetten kaynaklanan hak ve görevler bütünü olarak ifade edilir. Bu tanım, yurttaşlığın hak ve aidiyet boyutunu, genel hukuksal boyutunu belirtmekle beraber, siyasal ve özellikle sosyolojik boyutunu vurgulamakta zayıf kalmaktadır. Çünkü yurttaşlık, salt devlet merkezli bu tanımlamanın ötesinde hem farklı çıarların birbirleriyle hem de devletle olan mücadelesi sonucunda kazanılmıştır. Yurttaşlık, hem hukuksal eşitlik söylemi sayesinde hem de bireyleri toplumun eşit üyeleri haline getirmesi dolayısıyla çeşitli hak taleplerinin birbirleriyle çatıştı̆̆ potansiyeline sahiptir.

Böylece yurttaşlık, toplumsal birlik ve bütünlük oluştururken aynı zamanda bu birlik ve bütünlüğü zayıflatmada da önemli bir kavşaktır. Yurttaşlığın bu çelişkili anlamı sayesinde yurttaşlık hakları genişlemiş ve giderek daha fazla toplumsal kesim yurttaşlık haklarından yararlanmaya başlamıştır. Böylece yurttaşlık, Antik Yunan'dan günümüze değin çok çeşitli sosyal, siyasal, kültürel değişimlerin ve çatışmaların merkezinde yer almış ve evrensellik içeriği, iddiası sayesinde de sürekli genişleyen bir içerikkazanmıştır. Ancak, yurttaşlık konusundaki tartışmalara en son nokta hiçbir zaman konulamamıştır.

Batıda birkaç yüzyıllık toplumsal değişmenin ve gelişmenin ülkemizde -zaman zaman dramatik kopuşların da yaşandığı- onlarca yıla sığdırılmaya çalışıldığı 21. yüzyılın toplumsal ve siyasal tarihini, Türkiye insanının kulluktan tebaalığa, oradan da yurttaşlığa yürüyüşünün mücadelesi olarak özetlemek mümkündür (Ünsal, 1998).

Osmanlı İmparatorluğu'ndan Cumhuriyet'e, Cumhuriyet'in kuruluşundan günümüze kadar toplumsal yapımızdaki sosyal, kültürel, ekonomik ve siyasal değişimler ve dönüşümler, "yurttaş" oluşturma ve yetiştirmeyle ilgili anlayışın da değişim ve dönüşümlere uğramasına yol açmıştır. Tebaa'dan yurttaşa Cumhuriyet Türkiyesi'nde yurttaşlık ve kimlik sorunları hala tartışılmaktadır (Aybay, 1998).

Türkiye Cumhuriyeti'nin ilk yıllarında devletin, ulusun ve ulus devletin inşasında en önemli unsurlardan birisi hiç şüphesiz yurttaşl1k kurumu olmuştur. Cumhuriyet'in ilanının hemen ardından Mustafa Kemal'in dolaysız ve çok etkin katılımıyla belirlenen ve 1924 yılında okullarda zorunlu ders olarak okutulmaya başlanan Malumat-1 Vataniye dersi bu önemin en belirgin ve yalın göstergesidir (Üstel, 2004). Bu dersin verilmesine, daha sonra da Yurt Bilgisi ve Vatandaşlık Bilgileri adıyla devam edilmiştir. Böylece, Türkiye' de Cumhuriyet' in ulus ve yurttaşlık temelinde kendisini yeniden üretmesine ulusal eğitim bağlamında katkıda bulunulmuştur. Bugüne dek gelen süreç içerisinde, bir ulus yaratma amaciyla iç içe girmiş modernite projesi çerçevesinde yurttaşlı̆̆ın kendisi de inşa edilmiştir. Eş deyişle, yurttaşlık inşası Cumhuriyet'in kendini toplumsal ve siyasal anlamda yeniden üretmesiyle birlikte düşünülmüştür.

Yeni bir yurttaşlık kavramsallaştırması yaparken bu kavramsallaştırmanın temelinde ulusal kimliğin yattığı yadsınamaz bir gerçektir. Ulus kimliğini oluşturan, aktaran ve sürekliliğini kılan, ulusal eğitim politikalarıdır. Bu anlamda, uygulanan eğitim politikalarının ve dolayısıyla da eğitimin, bireylerin yurttaşlaştırılmasında önemli bir etkisi olduğu düşünülmektedir. Eğitimin 
ideolojik boyutu, yurttaş olma bilincinin yerleştirilmesinde önemlidir. Öte yandan, küreselleşme süreciyle birlikte, ulusal eğitim anlayışının yerini, ulus bilincinin göz ardı edildiği küresel eğitim anlayışı almaktadır. Dolayısıyla, ulus-devlet anlayışına bağlı yurttaşlık politikalarından küreselleşme anlayışına bağlı yeni bir yurttaşlık politikasına geçiş söz konusudur. Bu bağlamda tarihsel süreçte kimlik arayışında Yurttaş kavramı, Tebaa'dan Yurttaş'a ve Ulus-devlet yurttaşlığına geçiş ve küreselleşmeyle birlikte yurttaşlık kavramının dönüşümü tartışılacaktır.

\section{Araştırmanın Amacı}

Günümüzde yurttaşlığın sosyal, siyasal, kültürel ve demografik özelliklerinin edinildiği ulusdevletin sorgulandığı bir süreç yaşanmaktadır. Siyasal, sosyal, ekonomik ve kültürel alanda yaşanan değişim ve dönüșümler, modern yurttaşlığın eşitlik, katılım, evrensellik ve kamusallık gibi boyutlarının sorgulanmasını hızlandırmıştır. Eş deyişle, küreselleşmeyle, ulus-devlet egemenliğinin gerek tabandan, gerekse de üstten gelen baskılarla aşındırılma çabaları, artan göçler sonucu Avrupa'da oluşan çok kültürlü, çok ırklı toplumun sorunlarına ulusal kimlik politikalarının yanıt vermemesi, ekolojik hareket, kadın hareketi ve eşcinsellik gibi yeni toplumsal hareketlerin kendi söylemleri üzerinden kimlik politikalarının yeniden tanımlanması talepleri yurttaşlığı siyasal, sosyal ve ekonomik tartışmaların merkezi haline getirmiştir. Cumhuriyetin kuruluşundan itibaren yurttaşlığı ulusal bir ilke haline getirmeyi hedefleyen Türkiye bunu özellikle eğitim kurumu aracılığı ile gerçekleştirmeyi amaçlamıştır. Yurttaşlık eğitiminin ülkemizdeki serüveni bunun örneğidir. Cumhuriyetle birlikte siyasal, sosyal ve kamusal alanın inşasının en önemli öznesi olan birey, yurttaştır.

Çok sayıda etnik ve mezhep topluluğunun bir toplum yapısında, demokrasinin temel öncüllerinden yurttaşlık kurumuyla, bu toplum yapısını uzlaştırma, ulus-devlet modelinin karşısına çıkan en önemli sorundur. Oysa yurttaşlık kültürel farklılıkları ortadan kaldırır ve depolitize eder. Bireylerin ya da toplulukların hangi etnik yapıya, kültüre, mezhebe veya dine mensup olduklarına bakılmaksızın aynı haklara sahip olması gerektiği anlayışı yurttaşlığın en önemli özelliği, yurttaş olmanın olmazsa olmazıdır.

Küreselleşme süreciyle birlikte ulus-devlet yurttaşlığı içerik ve anlam kaybına uğramaktadır. Yurttaş kavramı modern içeriğine ulus-devlet anlayışı ile kavuşmuştur. Ulusdevlete zemin hazırlayan koşullar, yaşanan toplumsal ve siyasal değişmeler, ulus-devletin unsurlarını ve yapısını hazırlarken aynı zamanda, yurttaşın oluşumunun da koşullarını hazırlamıştır. Ulus-devlet ile yurttaş ilişkisi aslında, ulus-devletin yurttaş anlayışı ve istemleriyle eşitlik, özgürlük ve demokrasi arasındaki ilintinin tarihidir. Çünkü eşitlik, özgürlük ve demokrasi evrensel bir nitelik içerdiği için yurttaşlık kavramıda yerel niteliklerinden kurtulmakta, ulusala yaklaşmaktadır.

Son y1llarda ulus-devlet yurttaşlık anlayışı, küresel yurttaşlık anlayışına doğru yönelmektedir. Bunda temel etken Batı'nın kendi dışını "küreselleştirme” anlayışıdır. Küreselleşme, sermayemin ulus sınırını aşması dünya pazarının oluşumu ve bilgi teknolojisinin dünya ölçeğinde yaygınlaşmasını içeren bir süreçtir. Batı kendi yerelini küreselleştirerek, diğer tüm yerelleri yok etmeyi amaçlıyor. Küreselleşme evrensel ile tikelin karşl1ıklı etkileşimini dışta bırakan ve homojenleșmiş bir dünya tasavvuru yaratan bir süreç olarak algilanmaktadır. Küreselleşme toplumsal bir olgudur, ancak bütün toplumlar için doğal ve kaçınılmaz olduğu ise saçmadır. Ne yazık ki küreselleşme doğal bir süreç gibi algılanmaktadır. Toplumlar varlıklarını sürdürebilmek için hep ‘ötekini’ üretmişlerdir. Varlıklarını 'ötekini’ karşıtlığ 1 ile sürdürmüşlerdir. İlkel toplumlardan günümüze değin bu 'ötekine' egemen olma sürmüştür. Aynı zamanda her toplum ulus olma bilinciyle 'ötekine' karşı var olma savaşı vermiştir. Ulus-devlet, küreselleştirilen dünya da küreselleştirilen yurttaşa karşı ulus-devlet yurttaşlığını korumak için, bütün toplumsal kurumlarıla mücadele vermek zorundadır.

$\mathrm{Bu}$ araştırma, Türkiye'de modern yurttaşlığın oluşumunu, gelişimini, çözülüşünü ve alternatif yurttaşlık önerilerini, küreselleşme, çok kültürlülük, ulusalcıllk, ulusal eğitim ve ulus-devlet kavramlarıyla ele alıp incelemeyi amaçlamaktadır. 


\section{Araştırmanın Denencesi}

Denence: Yurttaşlık anlayışı, ulus-devlet anlayışından küresel yurttaşlığa doğru kaymaktadır. Bu yöneliş, Türkiye toplumunun ulusal egemenliğini temsil edecek etkili bir üst kimlik yurttaşlık anlayışında boşluk yaratmaktadır.

Denence: Yurttaşlığın sosyal, kültürel, demokratik özelliklerinin edinildiği ulusdevletlerin sorgulandığı bir süreç yaşanmaktadır. İçinde bulunduğumuz küreselleşme sürecinin, hem bu süreci anlamak ve art plandaki temel etmenleri çözümlemek, hem de yarattığı yenilikler ve sorunlar karşısında tavır almak gibi zorunluluklar nedeniyle birçok açıdan -özellikle yurttaşlık kavramı- tartışılması gerekmektedir. Küreselleşme kavramı hem küreselleşticiler hem de küreselleştirilenler olmak üzere farklı anlamlar içermekte olup yurttaşlık bağlamında ulus-devlet yapılanmasına olumsuz etki yaratmaktadır.

Bu çalışma yukarıda anılan denencelere dayanmaktadır: 'küreselleşme sürecinde ulusdevletlere ne olduğu -olacağı kadar, birey-toplum-devlet ilişkisinin temel aktörü yurttaşa ve onu yurttaş yapan siyasal ve sosyal haklarına ne olduğu- olacağının önem kazandığı' dır. Çok sayıda etnik ve mezhep topluluğunun bulunduğu bir toplum yapısında, demokrasinin temel öncüllerinden yurttaşlık kurumuyla bu toplum yapısını uzlaştırmanın, ulus-devlet modelinin karşısına çıkan en önemli sorun olduğudur.

\section{Yöntem}

$\mathrm{Bu}$ çalışmada kullanılan tarihsel yaklaşım (Kızılçelik ve Erjem, 1992), özellikle yurttaşlığın evrimindeki/ gelişimindeki tarihsel süreçlerle birlikte günümüze değin uzanan 'Yurttaşlık olgusu' üzerinde odaklanmayı ve belgesel gözlem tekniğine dayalı olarak yapılması planlanmıştır. Belgeler, diğer sosyal bilimlerle uğraşanlar kadar sosyologlar için de en önemli bilgi kaynağıdır. Sosyologu ilgilendiren, olguların ve toplumsal süreçlerin belgeler biçiminde bulunmasıdır. Belgeler yalnızca geçmişi değil, aynı zamanda günümüz toplumsal gerçeklerini de anlayıp açıklamaya yardımcı olurlar. Bu bakımdan kendileri de birer olgu durumundaki konuyla ilgili bilgi ve belgeler üzerinde çalışmaktadır.

\section{Bulgular}

\section{Yurttaşlık Kavramının Ortaya Çıkışı ve Gelişimi}

İnsanlığın tümünü kapsayabilme yeteneğine sahip kavramların kaderi, aslında farklı kürelere sahip olmaları gereken unsurların içine doldurduğu bir yamalı bohça, bir kırkambar haline gelmektedir. Böylece bu kavramlar 'köre göre fil' durumuna düştüklerinden, nihayete, somut gerçekliğe tekabül etmekten gittikçe uzaklaşarak, hayalet kelimelere dönüşme tehlikesiyle karşılaşmaktadırlar. Bu cins kavramların bir de tehditkâr yanları bulunmaktadır, bunlar çoğu zaman 'sihirli sözcük' olarak algılandıklarından insan-üstü, aşkın, her derde deva bir niteliğe bürünmelerinin yanı sıra, yalnızca adlarının telaffuz edilmesiyle kapıları açan bir içerik de kazanmaktadırlar. Dikkatler sihirli sözcüğün üzerine yoğunlaşınca, bunun içeriği istenildiği gibi doldurulabilir ve istenilen her şey onun anlamı ve yönü olarak sunulabilir. Kavramlar iyi tanımlanmış gerçeklere tekabül etme derecelerine göre 'yaşamsallık-hayatiyet' sahibidirler.

Her kavramın tanımlanmasında olduğu gibi, sosyal bilimlerin ilgi alanına giren yurttaşlık konusunun netliğine ilişkin çeşitlilik söz konusudur. Farklı noktalara vurgu yapılarak, yurttaşlık ile ilgili değişik tanımlar elde edilmiştir. Belirtilen bu tanımların her birinde farklı bir vurgu ön plana çıkmaktadır. Örneğin tanımların bazıları 'ulus-devlete' vurgu yaparken bazıları 'hak ve statüyü' vurgulamakta bazıları ise 'aidiyet ve kimlik' kavramlarını temel almaktadır.

Yurttaşlıktan söz etmenin temel güçlüğü, hem terimin müphemliğinden, hem de ona ait gibi gösterilen uzamsal ve işlevsel boyutlarının çeşitliliğinden (örneğin; aile, işletme, mahalle, 'dünya' yurttaşlığı) ve işaret ettiği ampirik konumlanışlarından (kendileri de farklılık gösteren 'özel' ve 'kamusal' nitelikli hak ve yükümlülükleri tanımlayan hukuksal konumlanış, özgülleşmiş rollerin bütünü, davranış çizgileri) kaynaklanmaktadır (Leca, 1996). Kavramın kendisi bir gerçeği ve hedeflenen bir ideali işaret ettiği için de sıkıntı doğurmaktadır. 
Yurttaşlık, ulus-devlet ile olan ilişkisi şeklinde ele alındığında, Latince civis ve Yunanca polities kökenleri itibariyle yurttaş, en basit anlamda "bir siyasal topluluğun üyesi" (Sarıbay, 1998) demektir. Belirli bir ülkenin vatandaşı olma halidir.

Geleneksel olarak yurttaşlık devlet ve bireyler arasında bir ilişki olarak kavramsallaştırılır (Desforges, 2004). Yurttaşl1k bir ulus devlete resmi üyelik (Marshall ve Battimore, 2000) anlamına gelir. Çağdaş biçimiyle yurttaşlık "bireyi ulus devlete bağlayan bir ilişkidir" (Erol, 1997). Yurttaşlık siyaset kuramı ile hukuk kuramında "bir ulus devletin ya da şehrin üyelerinin hakları ile ödevlerini anlatmak için kullanılır" (Marshall, 1999). Yurttaşlık ile ilgili olarak belirtilen bu tanımlarda bir siyasal topluluk, bu siyasal topluluğa resmi üyelik ön plandadır. Ulusdevletin sunduğu olanaklar içerisinde, bireylerin kazandıkları haklar ile edindikleri statüler yurttaşlık tanımlarında vurgulanan diğer noktalardır. Bu anlamda modern yurttaşlık kavramı "devlet ile olan ilişkilerinde bireyin sadakatini, haklarını ve ödevlerini ifade eden anayasal bir kavramdır" (Kaya, 2000). "Yurttaşlık toplumun üyelerine bağışlanan bir statüdür" (Marshall ve Bottomore, 2000).Yurttaşlık kişiler ve devletlerarasında anayasa ve yasalarla tanımlanmış karşılıklı hak ve ödevlere dayanan bağdır. En genel anlamıla teritoryal, yani bireyin devlete siyasal aidiyetin anlatımı olan yurttaşlık, bireyi bir dizi özel hak ve ödevin bağlı olduğu bir statüyle donatmaktadır. Ancak yurttaşlık yalnızca yasal statüyle sınırlı değildir, aynı zamanda "bireyin topluluğa eklemlenmesi, siyasal ve kamusal alanda kurduğu ilişkinin de ifadesidir" (Üstel, 1997, s. 128-129). Özel bir belirleme ile yurttaş, bir devlet içinde medeni ve siyasal haklara özellikle de seçme hakkına sahip olan kişidir.

Yukarda belirtilen bu tanımlarda yurttaşlık ile bireylerin hak ve ödevleri, bu hakların kişilere yasal statüler kazandırması, siyasal ve sosyal alanlarla çeşitli ilişkiler kurması vurgulanmaktadir.

Ulus devlet, hak ve statünün yanı sıra, aidiyete yapılan vurgulan ile dikkati çeken bir diğer noktadır. Dolayısıyla yurttaşlık kabaca bir devlete aidiyeti belirtir; kişiye bir takım hak ve ödevler içeren hukuki bir statü verir (Bilgin, 1998). Yurttaşlık sosyal grup müzakereleri ve bireysellikte sosyal işlemler seti olarak kavramsallaştırılmaktadır. Sadece hak, sorumluluk ve görev olarak değil aynı zamanda, toplumun çok kültürlülüğü içinde tam katılıma kuvvet veren, ait olma duygusu olarak da ifade edilir (Desforges, 2004).

Aidiyet duygusu olarak yurttaşlık, üç eksen üzerinde yer değiştirir (Leca, 1996).

1) Kuşatıcı gruba yaşadığı topraklar bakımından saptanabilen 'siyasal cemaat'ebir de, daha 'tikel' (çıkar grubu, sınıf, meslek birliği) ya da daha 'tümel' (kilise, ümmet, ihtilalci Enternasyonal) nitelikli başka gruplara dönük yönelimi ifade etmek üzere bir 'tikel-genel' ekseni;

2) Varoluşa iliş̧kin daha çok sicil/ geçmiş (aile, münazara cemaatleri, sınıflar, tarikatlar) barındıran daha 'tensel' daha 'talimatçı' gruplara ve genellikle yalnızca bir gruplara aidiyeti ifade etmek üzere bir 'cemaat-toplum' (ya da katılım sürecini daha iyi ifade eden Weber' gil terimlerle cemaatleme-toplumlama) ekseni;

3) Yerel (belde, kurul), bölgesel (federal bir devlete üye devlet, bölge), ulusal, uluslar üstü (gerekirse) cemaatlere aidiyeti ifade etmek üzere bir 'yukarı-aşağı' ekseni. Yurttaşlık ile ilgili olarak belirtilen diğer tanımlar ise şu şekildedir. Yurttaş "sunulan bir dizi seçenek arasından özgürce seçebilen bir tüketicidir" (Üstel, 1997).

$\mathrm{Bu}$ anlamda hür iradeye sahip olan bireyler, yurttaşlığın tasarımında önemlidir. Filozof Alain'e göre yurttaş "iktidarlara direnmesiyle tanımlanır" (Borne, 1996). Bu tanımda ise sorgulayan, karşı duruşlar sergileyen bireylerin önemine yer verilmiştir.

Yurttaşlık, hukuksal bir terim olarak, bir eylem teriminden ziyade, bir kimlik terimidir. Siyasal terim olarak baktığımızda, aktif bir adanmışlığı benimsemeyi ifade eden, sorumluluğa vurgu yapıldığını görülür. Bunun anlamı ise, kişinin, içinde yaşadığı toplumda 'fark yaratması' demektir (Varol, 1997). Bireyi ulus devlete bağlayan yurttaşlık ilişkisi "kamusal ve siyasal alanlarda bireyin cemaat aidiyetlerini, yani alt kimliklerini ikinci plana atmasını gerektiren bir üst kimlik kartı'dır, Varol ve Ünsal'ın tanımlamalarında ise 'kimlik' kavramını vurgulayarak yurttaşı sadece "devlete karşı ödevlerinin değil, haklarının da bilincinde olarak siyasal yaşama etkin bir biçimde katılabilen aktif bireyi tanımlamaktadır" (Ünsal, 1998). Yurttaşlık yine Leca'ya (1996, 
s. 62) göre "görece açık ve tek anlamlı bir nosyon ve Batı modernliğinin belirleyici vasfı olarak kabul edilir".

Yurttaşlık konusunda yukarıda aktarılan tanımların 1şı̆̆ında, genel görünüm şu şekilde belirtilebilir; Yurttaşlık, siyasal topluluğun üyesi olan, bu toplulukta kendisine sunulan hak ve görevlerle, yasal bir statü kazanan ve böylece belli bir ülkenin vatandaşı olan ve resmi bir üyelik kazanan, kamusal yaşama aktif olarak katılan, demokratik siyasal arenada özgürce seçebilen, yaptığı seçimlerle yeri geldiğinde iktidarlara direnme cesaretini gösteren ve bütün bu fonksiyonları içinde hiçbir sorumluluğu almaktan kaçınmayan bireyleri anlatmakta kullanılan, Batı modernliğinin belirleyici niteliği olarak kullanılan bir kavram olup, liberal anlayışta yurttaşlık devlet ile birey arasındaki hak ve sorumlulukları tanımlayan bir "sözleşme" (Arat, 1998) olarak vurgulanmaktadır. Liberal görüşe göre "yurttaşlık her kişinin kendisi için iyi olanı oluşturabilme, gözden geçirebilme ve rasyonel olarak uygulayabilme kapasitesidir. Yurttaşlar başkalarının haklarını çiğnememeleri için çizilen sınırlar içerisinde kendi çıkarlarına ulaşmak için haklarını kullanan kişiler olarak görünürler" (Mouffe, 1993). Liberalizm yurttaşlığı "sivil özgürlük"(Dietz, 1993) olarak algılar. "Yurttaşlık toplumda söz sahibi olamayanların daha fazla siyasi yetkinlik kazanıp kendi çıkarlarını daha etkili bir şekilde savunmalarına olanak veren bir kaynaktır" (Leca, 1993).

Liberal anlayış yurttaşlığı 'sözleşme' olarak kavramsallaştırılır ve yurttaş, iyiyi seçme, rasyonel düşünme ve hareket etme, her zaman başkalarının haklarına zarar vermeden kendi haklarını koruma ve kollama gücüne sahip olan bireydir. Yurttaşlık kavramının kökenini incelediğimizde, diğer kavramların ortaya çıkış ve gelişimlerine paralel olarak gözlemleneceği gibi tarihte toplulukların, toplumların sosyal, kültürel ve siyasal değişim ve gelişimlerine koşut olarak günümüze kadar gelmiştir. Bu değişimin serüvenini özetlersek; 'cite' den türeyen sözcük, başlangıç 'citeain' den sonra da 'citoıen' olarak yazılmış ve 17.yüzyıla kadar 'citoyen' , 'citodin' olarak, 'bir kentteoturan' anlamında kullanılmıştır.Tarihsel gelişimi içerisinde yurttaşlık kavram ve kurum olarak ilk kez antik çağda rastlanmaktadır, ancak yurttaşlık kavramının ilk izleri antik çağ öncesi dönemlerde de görülmektedir. Yurttaşlık, kent devleti öncesi dönemde, kabileler arasındaki savaşların gereklerinin ortaya çıkardığı ortaklık ve eşitlerin katılımı ilkesi ile gerçekleşmiştir. (Özkazanç,1998). Yurttaşlığın ‘bir kurum’ olarak ortaya çıkışı ise ilk kez Yunan polis'inde gerçekleşmiştir. "Başlı başına bir siyasal birim olması ve çeşitli tarihsel dönemlerde ortaya çıkan 'kent devletleri'nden toplumsal, ekonomik ve siyasal açılardan farklılıklar göstermesi nedeniyle 'polis' kavramının kullanılması yeğlenmiştir" (Ağaoğulları ve Köker, 2000; Köker, 2000, s. 11-12).

Yurttaşlığın gelişiminde Atina ve Isparta polisleri büyük önem taşır. Atina ve Isparta polislerindeki yurttaşlık anlayışı, modern yurttaşlıktan büyük farklılıklar gösterseler de, yurttaşlığın 'katılım', 'sadakat', 'eşitlik', 'ortaklık', 'kamusallık' gibi kavramlarını içermesi açısından modern döneme 1 şık tutmuşlardır. Bununla beraber, bu kavramlar dönemin koşullarına özgü anlamlar taşımaktadırlar ve bugünkü katılım, eşitlik anlayışının çok uzağındadırlar. Atina demokrasisi, yurttaşların yönetimde söz sahibi olmasına dayanan katılımcı bir özelliğe sahiptir. Isparta'da ise 'sadakat' ön plandadır. Savaşçı Isparta yurttaşı kendini Isparta'ya adadığı ve kahramanlık gösterdiği ölçüde değer kazanır (Reisenberg, 1992). Yurttaşlığın antik dönem teorisyenlerinin eserlerinde ahlaki bir erdem olarak değerlendirildiğini görüyoruz, ancak yurttaşlık bu dönemde, ahlaki erdemin yanı sıra, imtiyazlar ve görevler üzerinde şekillenen bir kurumdur.

Roma ise yüzyıllarca, yurttaşlık hukuku üzerinde şekillenen bir devlet kurmuştur. Yurttaşlığın Roma'daki gelişimi açısından patrici'ler ve plep'ler arasındaki sınıf mücadelesi ön plana çıkmaktadır. Cumhuriyet döneminde patrici'ler ve plep'ler arasında uzlaşma sağlanacak ve 'anayasal reformlarla yurttaşlık, soya değil; özel mülkiyet ve konaklama ilkesine göre düzenlenecektir (Ağaoğulları ve Köker, 2000).

İnsani ve mali potansiyelin etkin dağılımını gerçekleştiren yurttaşlığın Roma tarihinde iki önemli strateji izlediğini görüyoruz: Birincisi içerideki sınıf mücadelesini uzlaştırma ve kaynakların dağılımının yeniden düzenlenmesi, ikincisi ise bir genişleme stratejisi olarak, Roma şehri dışındaki halklara kendi yerel, etnik, dini kimliklerini korumakla beraber, sınırlı Roma 
yurttaşlığ tanıyarak bir üst kimlikle birleştirme. Böylece yurttaşlık kurumunun evrensel içeriği ilk kez Roma'da ortaya çıkacaktır (Reisenberg, 1992). Roma'da yurttaşlık erken dönemde sosyal ve siyasal değer ifade ederken, daha sonraları devleti bir arada tutma stratejisi olarak kullanılmış ve geç dönemde de sınıf kültürünü ifade eden bir kurum haline gelmiştir (Reisenberg,1992).

Ortaçağ kent devletlerinin gelişimi modern yurttaşlı̆̆a geçişte önemli bir aşamadır. Kentlerin özerklik mücadelesi, kentte yaşayanlar arasında kentlilik bilinci geliştirecek ve bu bilinç de, kent yönetimine yurttaşların katılımında somutlaşacaktır. Kent sakinlerinin kent yönetimine katılımları giderek cumhuriyetçi yönetim tarzının kent devletlerinde yaygınlaşmasını sağlayacaktır. Yurttaşla kent arasında kurulan aidiyet bağı ve yurttaşın kent yönetimine katılımı ve bu katılım karşılığında kentin korumasından yararlanması, modern yurttaşlığın haklar ve statü içeriğinin temellerini atacaktır. Orta Çağ kentlerinin gelişimi hem ekonomik hem de siyasal yapıda değişikliğin habercisidir. Ticaretin artması ile kentte yaşayan ve geçimini ticaretten sağlayan yeni bir toplumsal sınıf ortaya çıkmıştır. Bu dönemde antik dönemden farklı olarak, kırsal kesimdeki zenginlik kentlere aktarılmaya başlanmıştır. $\mathrm{Bu}$ da kentlerin giderek özerk birimler haline geleceğinin ilk habercisidir.

Orta Çağ kent devletleri, özellikle yurttaşlı̆̆ın 'katılım' boyutunu öne çıkarması ve kent ile yurttaş arasında kurduğu aidiyet bağ 1 ile yurttaşlığı bir statü olarak tanımlaması açısından modern yurttaşlık için önemlidir. Özellikle Machiavelli'de görüldüğü gibi ortaçağ kent devleti yurttaşlı̆̆l, kentin özgürlügü anlamında cumhuriyetçi idealleri yücelterek, yurttaşın kente aidiyetini, kent için savaşması gerekliliğini ahlaki bir erdeme bağlayarak modern yurttaşlığın temellerini atmıştır. 16. yüzyılın başlarında Avrupa, yurttaşlığın yaklaşık üç yüzyıl boyunca unutulacağı yeni bir döneme girmiştir. Mutlak monarşiler momentine rastlayan bu dönem, aslında birbirine zıt bir dizi gelişmeyi barındırır. Her şeyden önce 16. Yüzyıldanitibaren kapitalizmin yeni bir içerik kazandığını görmekteyiz. Büyüyen ticari girişimler, yeni pazarlar arasına girişecek, bu da merkezi yönetim ve hukuksal güvenlik arayışlarını beraberinde getirecektir. Bu arayışlara paralel olarak, kültürel birleşme, malların dolaşımı, siyasi merkezileşme, iş bölümünün artması, mesleki hareketlilik ve teknik bilginin gelișmesi de bu döneme rastlar (Leca, 1992). Mutlak monarşiler momentinin sağladığı en önemli dönüşüm, egemenliğin Tanrısallıktan kurtulmasıdır.

Egemenliğin Tanrısallıktan kurtulması, önce "bir devletin bekası için herhangi bir moral ya da hukuksal kaygıyla bağlı olmaksızın gerekli her şeyin yapılmasını öngören 'devlet aklı' söylemini" (Sancar, 2004), "mutlak monarşiden, meşruti monarşiye geçiş sürecinde ise, meşruiyetin ulusa dayandığını belirten 'hukuk devleti ve toplum sözleşmesi' söylemlerini (Özkazanç, 1998) beraberinde getirecektir”. Devlet aklı söylemi toplumun varlığını ve birliğini devlete bağlı kılarken, toplum sözleşmesi ve hukuk devleti söylemleri ise, devletin varlığını topluma bağlı kılma işlevi görerek, meşruiyetin “dünyevileşmesini' sağlayacaklardır (Özkazanç, 1998). Sancar'ın belirttiği gibi, devlet aklı söylemi feodal parçalanmışlıktan siyasi ve coğrafi merkezileşmeye gidilen süreçte, aşkın Tanrısal meşruiyetten, dünyevi meşruiyete geçişi, adeta devleti Tanrısallaştırarak, yani 'bir kutsalın karşısına başka bir kutsalı çıkararak' sağlamıştır. Böylece mutlak ve aşkın devlet iktidarı karşısında, yurttaşlık bir anlam ifade etmeyecek, tebaalıkla eş tutulacaktır. Bunun bir sonucu olarak mutlakiyetçi dönem, hem klasik anlamda yurttaşlı̆̆ın öldüğü, hem de modern yurttaşlık anlayışının nüvelerinin ortaya çıktığı dönemdir (Özkazanç, 1998). Klasik anlamda yurttaşlık ölmüştür, çünkü antik çağdan bu yana yurttaşlığın barındırdığı eşitlik, katılım, kamusallık, cumhuriyetçilik, zenginliklerin paylaşımı gibi anlamlar yok olmuştur. Modern yurttaşlığın nüveleri bu dönemde ortaya çıkmıştır, çünkü bu dönem, devlet ile toplumun iki ayrı varlık olarak ayrıldığı, bireylerin bir değer olarak değil, ama tebaa olarak devlet karşısında ' hiçbir şey' olmakta eşitlendiği bir dönem olmuştur. Tebaa olarak 'hiçbir şey' olmakta eşitlenme ise, liberal yurttaşlık geleneğinin ön koşuludur. Bir başka deyişle, mutlak monarşiler momenti, yurttaşlığın katılım, ortaklık, kamusallık, cumhuriyetçilik gibi boyutlarını silmekle beraber, devletin mutlak otoritesini vurgulamak ve toplumu bu otoriteye tabi kılmak amacıyla hareket etmesi sayesinde, modern yurttaşlığa gidilen süreçte devlet-toplum ayrışmasını mümkün kılmıştır.

Bununla beraber yurttaşlığın bir kavram olarak merkezileşmesi için Devrimler Çağı'nı beklemek gerekecektir.Modern yurttaşlığın içeriği Devrimler Çağı'na gelinen süreçte etkili 
olanideolojik tartışmalar tarafından belirlenecektir. Dönemin en önemli kavramlarından biri 'toplum sözleşmesi' dir. Toplum sözleșmesi, 17. ve 18. yüzyıllarda siyaset felsefesinin gündemine giren bir kavramdır. Modern yurttaşılı̆ın içeriği Devrimler Çağı'na gelinen süreçte etkili olan ideolojik tartışmalar tarafından belirlenecektir. Dönemin en önemli kavramlarından biri 'Toplum Sözleşmesi' dir. Toplum sözleşmesi, 17. ve 18. yüzy1llarda siyaset felsefesinin gündemine giren bir kavramdır. Özellikle Fransız devrimi ile başta kadınlar olmak üzere toplumun her kesimi dışlanma kavramından uzaklaştırılarak eşitlik temeli üzerine hak ve sorumululuklar temelinde yurttaşlı̆̆ın öncüsü olmuştur.

Özetlediğimiz siyasal ve söylemsel anlayışlar çerçevesinde kurulan modern yurttaşlık, feodalizmin hiyerarşik toplum yapısına karşılık, hukuken eşitlenmiş birtoplum yapısı oluşturulmasını olanaklı kılmıştır. Öte yandan modern yurttaşlığın ortaya çıkışı, kapitalizmin gelişimine paralel bir şekilde gerçekleşmiştir. Eşitlikçi bir söylem ile gelişen yurttaşlık kavramı ile toplumsal eşitsizliklerin kaynağı olan kapitalizmin nasıl olup da bir arada gelişebildiği yurttaşlığın temel sorularından birisidir. Kapitalizm feodal yapıdaki hiyerarşik sınıf yapısının aksine 'akışkan' bir toplum gerektirir. Bu akışkanlığı da kısmi bir eşitlik sağlayan şekli hukuk kurallarıyla, yani yurttaşlık haklarıyla elde eder. $\mathrm{Bu}$ arada sosyal eşitsizliklerin kaynağ 1 kapitalizm ile eşitlik söylemi üzerine kurulan yurttaşlığın nasıl olup da bir arada yer aldığı önemli bir sorun olarak karşımıza çıkmaktadır.

$\mathrm{Bu}$ sorunu ilk ortaya koyanlardan biri T. H. Marshall'dır. Marshall yurttaşlıkla ilgili analizlerde en çok başvurulan referans kişidir. Marshall'e göre yurttaşlık bir topluluğun üyelerine bahşedilen bir statüdür. Van Steenbergen, Marshall'in (1994) bu tanımının politik olmaktan ziyade, sosyolojik olduğunu ileri sürer. Yurttaşlığın gelişimini Britanya'daki tarihsel süreç çerçevesinde ele alan Marshall, 18. yüzyılda hukuk mahkemelerinin kurulmasıyla medeni (bireysel) hakların, 19. yüzyılda genel oy hakkının elde edilmesiyle siyasal hakların ve 20. yüzyılda da eğitim, sağlık, sosyal güvenlik hakları gibi haklar ile sosyal hakların kurumsallaştığını belirtmiştir. Marshall'a göre, sosyal eşitsizliklerin kaynağ üzerine kurgulanan yurttaşl1k, sosyal haklar sayesinde bir arada yaşayabilmektedir. Sosyal haklarla yurttaşl1k son aşamasına gelmiştir (Marshall, 2000). Marshall, Britanya örneğini evrensel bir model gibi sunması ve ulus devleti tek veri olarak kabul edip farklı toplumsal dinamiklerin ve toplumsal mücadelelerin yurttaşlığa olan katkısını göz ard1 etmesiyle, yurttaşlığ 1 'apolitikleştirdiğgi' şeklinde eleştirilmiştir. Özkazanç'ın belirttiği gibi, Marshall, merkezi önem verdiği haklar pratiğinin içinde yer aldığı modern siyasi topluluğun niteliğine dair hiç dile getirilmeyen birçok varsayımdan hareket etmiştir. Bu nedenle sözünü ettiği üç tür hak arasındaki kavramsal, mantıksal ve ontolojik ilişkileri kuramamış ve bunlar arasındaki muhtemel çelişki ve çatışma potansiyellerini göz ardı etmiştir (1998, s. 101-102). Marshall bu analizinde yurttaşlık, ulus-devlet ve sanayi kapitalizminin tek veri kabul edildiği apolitik bir söylem oluşturur.

Modern yurttaşlığın evrimini incelediğimizde yurttaşlık haklarının toplumsal iktidar mücadelelerine paralel bir şekilde geliştiğini, giderek daha fazla toplumsal kesimin bu haklara dâhil edildiğini görmekteyiz. Ancak yurttaşlık hakları sadece aşağı sınıflardan gelen, taleplerle genişlememiştir, kimi durumlarda da, güvenlik gerekçesiyle, egemen sınıflar da çeşitli toplumsal kesimlerin yurttaşlık haklarına dâhil edilmesini sağlamıştır. Bir başka deyişle, "yurttaşlık haklarının doğuşu, gelişmesi ve genişlemesi kapitalist toplumda sınıf güçlerinin değişen ihtiyaç ve kapasitelerine göre belirlenmektedir" (Barbalet, 1988). Bu ihtiyaçlar kimi zaman, aşağı sınıfların sistemden dışlanmasını gerektirebileceği gibi, kimi durumlarda da, sisteme dâhil edilmelerini gerektirebilir. Böylece yurttaşlık hem toplumsal mücadelelere zemin hazırlayan, hem de toplumsal bütünleşmeyi sağlayan bir içeriğe sahiptir. Yurttaşlığın, ilk ortaya çıkışından itibaren, kaynakların paylaşımında rol oynaması sürekli çıkar çatışmalarının merkezinde yer almasına neden olur. Böylece "yurttaşlığın hem yönetici sınıf, hem de ezilen sınıf stratejisi olarak ikili bir nitelik taşıdığını, bu nedenle bir yandan toplumsal bütünleşme arayışını ifade ederken bir yandan da, yeni çatışma zeminleri yarattı̆̆ını görmekteyiz" (Özkazanç, 1998). Bunun bir sonucu olarak, yurttaşlık her dönemde faklı kesimlerin kendi çıkarları üzerinden tanınmamak istedikleri bir alan olarak belirecektir. Bir başka deyişle, Marshall'ın belirttiğinin aksine, yurttaşlığın kesin 
ve nihai bir tanımı hiçbir zaman yapılamayacak, her dönemde içeriği farklı söylemlere göre değişecektir.

\section{Tarihsel Süreçte (Osmanlıdan Cumhuriyet'e) Kimlik Arayıșı: Tebaa, Yurttaş ve Ulus- Devlet Yurttaşlığı}

Modern ulusal kimlikler feodal üretim biçimlerinden kapitalist üretim biçimlerine geçerken şekillenmişlerdir. $\mathrm{Bu}$ geçişin tarihi sırası ve devrim veya evrim şeklinde ortaya çıkışı ulusal birimlerin temel niteliklerinin oluşmasında önemli bir rol oynamıştır. Batı'da savaşçı aristokratların yerini, fetihçi burjuvalar değişik yöntemlerle almışlardır. Bu fetihçi burjuvalar Batı'nın ortak değerlerini, aristokrat kültür mirasıüzerine oturturken, değişik yol ve yöntemleri de ulusal karakterlerin oluşmasına katkı yapmıştır: İngilizlerin pragmatizmi ve iktisatçılığı, Fransızların despotik iktidarı karşı kavga ile beslenen devrimcilikleri, Almanların gecikmiş kapitalizmleri ve kuramcılıkları vb. hep bu bağlamda değerlendirilmiştir. Burada dikkati çeken ise, Osmanlı Devleti'nin fark1 ve özgüllüğüdür. Osmanlı Devleti'nde modern ulus-devlete temel teşkil edecek, etnik ve kültürel açıdan türdeş bir halk tabanı olmamıştır. Müstakbel Türk ulusunu oluşturacak öğeler Anadolu'da bile bir bütünlük göstermemiştir. Çağdaş Türk ulusunu, Anadolu, Balkanlar ve Kafkasya'nın Türkçe konuşan Müslümanları uzun ve yorucu bir ölüm-kalım savaş1 sonunda buluşarak gerçekleştirilmiştir.

$\mathrm{Bu}$ halkı bir araya getiren ve kenetleyen, birbiriyle yakından ilişkili iki unsur vardır: Bunlardan birincisi, ortak anılar ve emperyal gelenektir; ikincisi ise, toplum düzeninde işgal ettikleri yerden doğan hâkim millet bilinci ve kendilerini tüm imparatorluktan sorumlu kılan üstünlük duygusudur. Örneğin, Osmanlılar 19. Yüzyılda üstünlüklerini kaybettikleri ve 'hasta adam' konumuna düştükleri anda bile bir üstünlük duygusundan ve gururlarından kendilerini kurtaramamıştır. Ne var ki bu temelsiz gurur artık tutucu bir işleve bürünmüş, tartışmasız değer olan 'ulusal onur'a ters düşmüş ve siyaseti tekelci bir konuma çıkardığı ölçüde, yeniçağa damgasını vuran iktisadi gelişmelere fren olmaya başlamıştır.

Osmanl1-Türk ulusal karakterinin hâkim unsuru, bu bağlamda, siyasetle belli bir ilişki içerisinde kendini göstermiştir. Toplumsal kökenleri ve sinıfları ne olursa olsun, onlar için her şey siyasi ve tüm Hikmet-i Devlet'ten sorumludurlar. Timur, böyle bir yaklaşımın sınıf bilincini engellediğini, kendisini "Devlet sayan bir orta sınıf espirisini herkese egemen kıldığını ve belli bir Osmanlı megolamanisini sürdürdüğünü ifade eder" (1986, s. 119-163). Yani, en yoksul Türk bile, fantezi dünyasında, yönetici zümre ile özdeşleşiyor ve kendini onun bir parçası olarak görüyordu. Tabi bu durum yöneticilerinde işini kolaylaştıran bir haldi. Bu yüzden, halktan gelebilecek bir tepkiden çekinmeden her türlü iç ve dış çıkar gruplarıyla (yabancı elçiliklerle, bankerlerle, sarraflarla vb.) ittifaka geçebiliyorlardı. Osmanlının ümmetçi kişiliğinden ulusal kimliğe geçiş sürecinde potansiyel Türk, üst perdeden konuşan bir siyasetçi giysilerine bürünmüştür. En altta, en ezilen sınıflara mensup olsa bile, daima "yaşasın devlet!" demiştir. Devlet kavramı ve devletçilik, her zaman samimiyetle olmasa bile, Türk'ün yaşam felsefesi, ikinci doğası haline gelmiştir.

Orta sınıf kökenli asker- sivil aydınlar kadrosunun iktidara damgasını vurduğu, II. Meşrutiyet dönemi, ideolojik olarak ta, Türkçülüğün egemen konuma geçtiği bir dönemdir. Ve siyaset tepeden tırnağa her şeye etki eder bir hal almıştır. Meşrutiyet aydını, siyasi oluşunun dışında, "Osmanlı gururu"nun da mirasçısıydı. Bu gururu Timur şu şekilde betimlemektedir:19. yüzyılın çöküntüsü içinde, muhtemelen Sasanilerden kaynaklanmış olan Acem palavracılığıyla özdeşleşmişti. Fakat yine de, Tanzimat insanı "Devlet haşmeti"ni politikacılardan ayırmasını bilmiştir. O dönemde Osmanlı gururunu Sultan temsil ediyor ve "Dar'ül Harb"e karşı dik tutmaya çalışmıştır. Abdülaziz, ilk kez bir Osmanlı sultanı olarak Avrupa seyahatine çıktı̆̆ında, görülmemiş bir karşılama merasimi yapılmış, Osmanlı padişahı 14. Louis'nin müzeden çıkarılan yaldızlı arabasına bindirilmişti. Buna karşılık Tanzimat paşaları, "Düvel-i Muazzama"nın elçileri karşısında bile düşük profil takınmışlardır (1998). Bu durum, Osmanlının yarısömürge durumunu çok net olarak gösteriyor ancak Meşrutiyet aydını hala gerçekçi olamıyor, yeni imparatorluk hayalleri peşinde arayışlarda bulunuyordu (Timur, 1986, s. 134-138). 
Osmanlılık, Türkiye Cumhuriyeti kimliğine giden yol üzerinde can alıcı bir yeri vardır. Türkiye' de ve Batı'da Osmanlılığa olumlu bakılmadığı bilinen bir gerçektir. Cumhuriyet rejimi, Osmanlılığın Saltanatı ve Halifeliği temsil etmesi nedeniyle siyasi rakip olarak görmüş ve reddetmiştir. Hatta Ziya Gökalp, Osmanlılı̆̆ , Türk Milletinin ulusal dil ve kültürünün gelişmesini önlediğini ifade etmiştir. Ayrıca, Gökalp Osmanlının bir üst dil ve kültüre sahip hâkim bir sınıf yarattığı için, idare ettiği halktan ayrı yabancı bir sosyal grup oluşturduğunu belirtir. Bu durumda Cumhuriyet yöneticilerinin Osmanlıya sırt çevirmeleri ve ulusal tarihi 1923'den başlatmaları yadırganmamalıdır. Ancak bir gerçeklik olarak yurtlaş oluşturma politikaları ve Cumhuriyet kendi toplumunun temelinde yatan kolektif bir dayanışmayı ve kimliği Osmanlı'nın hazırladığını görmezden gelmez. Yani Osmanlının hazırladığı sosyopolitik kültür ve toplum Cumhuriyet'in yaratılması, kurulmasının zeminini oluşturmuştur. Kısaca Osmanlı olarak doğan, eğitimini Osmanlı okullarında alan, ilk siyasi kimliklerini Osmanlı olarak tanımlayanların bir anda 'Türk' ve 'Cumhuriyetçi' olmaları ve bu değerler köklü bir şekilde bağlanmalarının altındaki gerçeklik yeni kimliklerinin aslında eski olanın 'millileşmesi'dir.

Eski Devlet-i Ali-i Osman Osmanî bir hanedan devleti idi. Bu kimliğini de tebaasının etnik ve dil kimliği yapısından almadığı da bir gerçekliktir. Bunun yanı sıra devletin dili Türkçedir. Örneğin devlet, hanedan devleti olmadan önce "Osmanoğulları" olarak bilinirdi. Din de Müslüman tebaa ile hanedan devleti birbirine yakınlaştırır ve gayrimüslimlerden ayırırdı. Klasik devletler, din, dil, kavim, soy ve bunların doğurduğu hukuki-siyasi düzen ve onun kültüründen oluşur. Burada dinin siyasi sistemin en önemli destekçisi olduğuna dikkat çekmek yerinde olacaktır. 'Osmanlılık' kavramının içeriğinin iyi anlaşılmasıyla doğurduğu siyasi kimliklerin doğru değerlendirilmesini ve Türkiye Cumhuriyeti kimliğinin daha sihhatli değerlendirilmesine yardımcı olacaktır.1839 Tanzimat ve özellikle Islahat Fermanı, idare eden (devlet) ve idare edilen (tebaa) arasındaki geleneksel siyasi ilişkileri yeni bir esas üzerine kurmayı amaçlıyordu. Bu yeni esas, batı'nın baskısı ile kabul edilen 'kişi' temeline kurulmuş devlet olup temeli de 'vatandaşlık' esasına dayanmaktadır. Biraz önce ifade edildiği gibi bu da 'Islahat Fermanı'na dayanmaktaydı. Kısaca artık kişi devletin temelini oluşturuyordu.. Vatandaşlık eskiden padişah ve tebaanın arasında sultana itaati esas alan kişisel ilişkiler yerine tebaayı vatandaş yaparak onu devlet ve devleti idare edenlere bağlamıştır. Devlet padişahın şahsında simgelenen kişisel bir varlık olmaktan çıkarak soyut bir içerik kazanmıştır. Gerçi Sultan devlet başkanı olarak görünmeye devam etmişse de o eskiden olduğu gibi devletin mutlak maliki sahibi değil, devletin bir organı haline gelmiştir. Bunu modern, Batı devlet modeline giden büyük bir adım olarak değerlendirmek gerekir. Böylece Osmanlı ilk kez kişiyi devletin temeline koymuş ve siyasi bir varlık olarak tanımışır. II. Mahmut zamanında çıkarılan mürûr teskeresi (seyahat vesikası) bir süre kimlik ve pasaport olarak kullanıldıktan sonra hüviyet teskeresi, hüviyet cüzdanı isimleri ile bu gün kullandığımız anlamda nüfus cüzdanı haline gelmiştir. Bu cüzdan kişiyi padişahın kulu (tebaası) olmaktan çıkararak devletin 'vatandaşı 'olduğunu simgeleyen belge halini almıştır. Osmanlılığın, vatandaşlar arasında din, dil, mevki farkı gözetmeksizin hukuki bir eşitlik getirerek teorik olarak devleti vatandaşların sahip oldukları bir kurum haline getirmiştir. Cumhuriyet'teki halkçılığın, yani demokrasinin bir ifadesi olarak “demokrasi” nin temelini atmış oldukları belirtilir. Daha, 1920'de Atatürk halkçılı̆̆ın devletin halkın idaresi manasına geldiğini ifade etmiştir. 1876 I. Meşrutiyet'i, eşit ilan edilen vatandaşların devlet yönetiminde söz sahibi olmasını amaçladığı için, demokrasiye giden ilk adım olarak görmek olasıdır. Fakat 'eşitliği' uygulayacak bürokrasi kendini 'halk' olarak görmüş ve 'halk' adına siyasi gücü kendi elinde toplamıştır.

Diğer yandan da yeni Osmanlılık, klasik devletin temeli olan cemaati bir yana bırakarak ferdi esas alarak beklenmedik ayrılıklara yol açarak siyasi kimliğin din üzerine kurulması ile sonuçlanmış ve bu da nüfusu ikiye bölmüştür. Böylece hem Batılılar hem de Osmanlı idarecileri değiştirmeye kalktıkları devletin 'niteliğini' anlamadıkları için modernleşmeyi de yanlış yola sürüklemişlerdir. Bu değişimi kısaca özetlersek: Bilindiği gibi klasik Osmanlı devletinin cemaat yapısı her cemaate, yani din esasına göre kurulan 'milletler' ve her 'milletin' içinde bulunan etnik ve dil gruplarına kültür, eğitim, aile hukuku alanlarında mutlak otonomi tanıyarak devleti bu hakların ve otonominin koruyucusu haline sokmuştur. Devlet, Müslüman'dı fakat bir anlamda 
çeşitli dinlere -İslam'a üstünlük tanımakla birlikte- eşitlik sağlamasıyla 'laik'ti. Devlet gayrimüslim gruplara verdiği kültürel-dini- hukuki otonomiyi İslam'ın geliştirdiği 'zımni' (İslam devletine tabi olmuş, korunmuş) kavramından hareket ederek yapmıştır. Fakat klasik Osmanlı devleti bu İslami prensibin ana esaslarına bağlı kalmakla beraber patrikhanelere ve onların meclislerine verdiği etkilerle bu zımniliğin anlamını hayli genişletmiş ve değiştirmiş ya da zorunda kalmıştır. Burada dikkat edilmesi gereken konu ise, bu düzenin baş destekçisini 'kilise' olmasıdır. Bu sayede gayrimüslim milletler ve onların etnik birimleri Osmanlı idaresi süresince padişahın tebaası olarak evrim ve değişme geçirerek sürekli gelişmiş ve güçlenmiştir. Böylece kilise sanatı, gayrimüslimlerin ticaret hayatı, okul ve sistemi hiçbir zorlama görmeden kendini geliştirme olanağı bulmuştur. 19.yüzyılda Islahat Fermanı'nın gayrimüslimlere sağladığı 'eşitlik' statükosu ve Batı'nın ekonomik ve eğitim desteği ile bu gayrimüslim cemaatleri Müslümanlara göre çok daha hızlı modernleştirerek içinden etnik ve dini bilince sahip yeni bir orta sınıf doğurmuştur. Sonuçta din eşitliği üzerine kurulmuş olan klasik Osmanlı devleti -Osmanlılık sayesinde- Müslüman ve gayrimüslimleri birbirlerine rakip hatta düşman haline getirmiştir. Osmanlılık devleti cemaat esasına ayırarak kişiyi devletin temeli yapmaya ve onun üzerine kurmaya (sonuçlarını da pek düşünmeden) karar verip buna göre yeni bir düzen uygulamaya başlayınca eski dini, dil kimlikler 'milli' kimliğe dönüştürerek Müslimler ve gayrimüslimler arasında beklenmedik bölünmelere ve ihtilaflara yol açmıştır. Osmanlı devletinin akıbetini de bu ayrılıklar belirlemiştir. Eskiden din, dil vb. temel toplum özellikleri devlet üstü adeta Tanrı'nın verdiği ve kulların değiştiremeyeceği temel haklar olmaktan çıkarak devletin iradesine bırakılmış bir tür lütuf haline gelmiştir. Osmanlılık'ın eşit vatandaşlık sayesinde bu ayrılıkların üzerin çıkarak devletin parçalanmasını önleyemeyeceği kaçınılmazdı. Fakat Müslim ve gayrimüslim farkları halen devam etmek ve siyasileşmekte çünkü devletin 'sahibi' Müslümanlar olup diğerleri azınlık olmuştur. Nasıl ki bugün bir gayrimüslim, yurttaş olarak 'Türk’tür ancak toplum gözünde 'Türk' değildir.

Osmanlıl1k 19.yüzyılda devlete siyasi bir kimlik vermiş ve bu kimliği eninde sonunda çoğunlukta olan tebaanın devlete fiilen hâkim olan elitler ve onların kültürü tayin etmiştir. Burada garip olan ise, modernleşmeden evvel devletin siyasi kültürü olarak halk kültüründen görece farklı olmasına rağmen devletin halkın isteklerine ve kültürüne yani dine uymak zorunluluğu (şeklen "şeriat isteyerek" yeniçeri isyanlarına boyun eğmekle beraber) yoktu. Devletin idare ettiği halktan sosyal bakımdan kesin olarak ayrılması, yani reaya ve askerleri arasında duvarların aşılmaz olması devleti tebaaya hesap vermek zorunluluğundan muaf tutuyordu. Bunun yanı sira devletin aslını değiştirdiği iddia edilen "ulema" tarafında eleştirilen Tanzimat Fermanı aslında devleti başka kapıdan geçerek İslamlaştırmış ve modernleştirmiştir. Bu aslında yeni tip bir İslamlaştırma olup halkın çoğunluğunun kültürüne de uygun gibi gözükmektedir. Bunu, hoşgörüyü esas tutan bir İslam olarak ifade eden ve milli olarak ta kabul edildiği iddia edilen bir İslam'dır.

$\mathrm{Bu}$ bağlamda Osmanlı İmparatorluğunun son dönemleri yoğun bir şekilde kimlik arayışları, tartışmaları içinde geçmiştir: Osmanlı kimliğini tanımlamada başlıca üç sav (Osmanlıcılık, İslamcılık ve Türkçülük) ya da Yusuf Akçura'nın deyimi ile 'üç tarz-1 siyaset' ön plana çıkmıştır. Mustafa Kemal Atatürk'ün 22.05.1919'da Samsun'dan Sadaret'e yazdığ raporda, Erzurum kongresi Bildirisinde ve Sivas Kongresi Bildirisinde ilk dikkati çeken konu; "Türklük, Türk Milleti ve Türk Milliyetçiliği 'gibi deyimlerin hiç kullanılmamış olmasıdır. Buna karşılık, ulusal topluluğun Osmanlılık ve Müslümanlık gibi geleneksel ölçütlerle tanımlanmış olduğu görülmektedir. Daha da önemlisi, bu topluluk yekpare bir kütle olarak algılanmamakta, onun çeşitli unsurlardan meydana geldiği vurgulanmaktadır. Bu unsur 'bilcümle anasır-1 İslamiye' olarak belirtilmiştir. "Bu çeşitli unsurları birbirine bağlayan bağlar 'öz kardeşlik', "karşılıklı saygı ve fedakârlık duygusu", "saadet ve felakette ortaklık", "aynı mukadderatı paylaşma" arzusudur" (Özbudun, 1997). Buradaki belirsizliklere yani ulusal bir kimlik inşasındaki ölçütlerin oluşturulmasının açıklamasına geçmeden önce, "devletin nasıl kurulacağına ilişkin olarak ilk belirtilmesi gereken, Osmanlıcılık, İslamcılık ve Türkçülükten oluşan üç tarz-1 siyasetin "eklektik" çözümlemeleri açıkça reddedilmiştir" (Yıldız, 2001). İlk defa Balkan Savaşları (1913) sonucunda imzalanan barış antlaşması sonucunda çizilen ve Milli Misak'la teyit edilen sınırlar, yeni Türkiye Cumhuriyeti'nin değişmez sınırları olmuş ve bu 
mülkilik, İslami bir referans taşımadığı gibi, ulusallığın Mustafa Kemal Paşa tarafında yapılan yorumu, daha "evrensel" nitelikler taşıyan pantürkçü ve panislamist referansların reddine dayanmaktadır. Ancak, daha önce vurgulanan çeşitli unsurları birbirine bağlayan bağların açık/ açılayıcı olmadığı görülmektedir. Örneğin yukarında anılan üç bildiride de ortak ifadeler vardır: "Bu unsurların hukuk-u irkiye ve içtimiyelerine ve 'şeraitî muhitiye'lerine 'tamamen riyatkâr' olunacağından söz edilmektedir” (Özbudun,1997). Yani, ırksal ve toplumsal haklarına ve çevre şartları ve özelliklerine göre tamamen uyulacaktır. Bu kavramları açıklığa kavuşturulması beklenen Erzurum ve Sivas Kongrelerinde hiçbir bilgi verilmemesi de ilginçtir. 'Irksal ve toplumsal haklar' nelerdir, 'çevre şartları' ile ne anlatılmak istenmektedir ve bunlara tamamen riayet nasıl sağlanacaktır? Bu belirsizliklere rağmen sözü edilen belgelerde verilmek istenen mesajın, kültürel kimlikler bakımından çoğulculuğu benimseyen, hatta bu kimlikleri hukuksal planda koruyan ve güvence altına alan bir 'çeşitlilik içinde birlik' mesajı olduğu açıktır. Unsurların 'şerait-i muhutiyelerine' riayet ise, geniş kapsamlı bir yerinden yönetim olarak yorumlanabilir.

II. Meşrutiyet, cumhuriyet yurttaşlığının iki damarını yaratmıştır: Fransızvari siyasal ulus ve yurttaşlık anlayışıyla Almanvari organik ulus yaklaşımının eşanlı birlikteliği, II. Meşrutiyet okullarında öğrenim görmüş Cumhuriyet eğitimcilerinin ileriki yıllarda belli başlı açmazını oluşturacaktır. II. Meşrutiyet yurttaşlığından Cumhuriyet yurttaşlığına devredilen "süreklilik unsurlar”, büyük ölçüde Meşrutiyet eğitimcilerinin zihinsel ufuklarını II. Cumhuriyet Fransa'sına çevirmiş olmalarından kaynaklanmaktadır. II. Meşrutiyet'in eğitimci ve kitap yazarları, ulusdevlet yurttaşlığını, ulus-devletin yokluğunda inşa etmeye çalışmışlardır. Cumhuriyetçi anlayış ise, bir yandan II. Meşrutiyet'in 'katılımc1-sivil yurttaşl1k' vurgusunu, ulus-devlete bütünüyle sadakat ve aidiyetin ifadesi olan militan yurttaşlığa doğru dönüştürmeye zorlayacak, diğer yandan da Balkan Savaşı sonrası güç kazanan Türkçü-ulusçu ideolojiyi ve onun ulus hayalinin organiketnik boyutunu bürokratik ulusçuluk ile harmanlayacaktır.

\section{Ulus-devlet Yurttaşlığı ve Bir kimlik İnşası}

Türkiye Cumhuriyeti'nin başlangıcı, kuruluşu anayasalarını ve Atatürk'ün söylemlerini göz önüne alarak bir bütün halinde değerlendirdiğinde, Cumhuriyet'in temel ilkeleri itibariyle Kant'tan Fransız devrimine uzanan bir anlayışla devam ettiği söylenebilir. Bu anlayış, ulusdevletlerin oluşumunda ve İnsan Hakları Evrensel Bildirgesi'nde vücut bulan ilkelere dayanmaktadır. Burada özellikle üç nokta belirleyici özelliğe sahiptir. Birbirini tamamlayan bu üç noktadan birincisi Cumhuriyet fikri, ikincisi ulus anlayışı, üçüncüsü ise, modernleşmeci perspektiftir. $\mathrm{Bu}$ üç öğede Türkiye Cumhuriyeti'ni anlamak bakımından büyük önem taşımaktadır.

$\mathrm{Bu}$ önemi Lewis (1997, s. 204), şöyle özetler; "Türkiye Batılılaşamamış ama modernleşmiştir", Lewis bu yorumuyla, "Türkiye'nin biçimsel açıdan önemli değişimler geçirdiğini, fakat Batı uygarlığının temel değerlerini henüz benimseyemediğine" de ayrıca dikkat çekmiştir.

Türkiye'nin kendine özgü koşulları, Türk Devrimi'nin gerçekçi bir şekilde değerlendirilmesi için, Batılı bilim insanlarının geliştirdiği modernleşme modellerin koşullanmalarından kurtularak (ancak bu modelleri de akılda tutarak) yapılabilir. Yani Türk Devrimi'nin değerlendirilmesi için iki ön koşul sayılabilecek bakış açılarını değerlendirmekte yarar var. 1) Batılı modellerin koşullandırmalarından kurtulmak ve 2) bunları göz ardı etmemek, Türk Devrimi'nin kendine özgü toplumsal yapısını dikkate almak.

Batılı modellerin koşullanmalarından kurtulmak, Türkiye'nin toplumsal yapısının Batı'dan farklı olmasının yanında, dış dinamik bakımından dünya üzerindeki konumunun Batılı ülkelere benzememesinden kaynaklanmaktadır. Bunu bir başka şekilde şöyle açıklayabiliriz: Birinci olarak, "Türkiye'nin Selçuklu- Osmanlı çizgisindeki yapısı Batı'daki feodalizmin ve kapitalizmin gelişmesinden çok farklı bir çizgi izlemiştir". Batı toplumları için geçerli olan ve onların yapılarına uygun olarak ortaya konan modellerin, Osmanl1-Türk toplumsa değişme çizgisini açıklamakta yeterli olmamaktadır. İkinci olarak, Osmanlı İmparatorluğu yarı-sömürge durumuna düştükten sonra, artık tümüyle başka bir dinamik rol oynamaya başlamıştır” (Kongar, 
1979, s. 53- 88). Yani, Türkiye'nin Batı toplumlarının izlediği gelişme çizgisini izleme olanağı tümüyle ortadan kalmıştır. Çünkü yarı-sömürgeleşme süreci sonucunda, daha önce merkez-çevre kuramının mekanizmaları ortaya çıkmıştır. Yani, Türkiye, uçağı, televizyonu, bilgisayarı olan geri teknoloji ülkesi konumuna düşmüştür. Avrupa'nın hiçbir döneminde böyle bir olgu, yani emperyalizmin boyunduruğunda 'geri teknoloji ülkesi' daha yaygın deyimi ile 'az gelişmiş ülke' olma durumu söz konusu değildir. Gerek Mustafa Kemal Atatürk Türkiye'sinin, gerekse günümüz Türkiye'sinin benzerini, Batı toplumları, tarihlerinin hiçbir döneminde yaşamamışlardır. İşte bu nedenlerden dolayı, hem iç dinamiğe, hem de dış dinamiğe bağlı olarak, Batı toplumları için geliştirilmiş olan modeller, Türkiye için pek de geçerli değildir. Bu bağlamda, modernleşme politikaları dünyanın her yanında ulus-devletlerin hayata geçirilmesinde vazgeçilmez bir enstrüman olarak düşünülür. Her ulus-devlet kuruluşundan itibaren, coğrafi sınırları içerisinde bulunan halkı, belirli idealler, değerler, inançlar, tutumlar etrafında birleştirme/ bütünleştirme; eğitim ve dil birliği sağlama; çeşitli sosyal kesimler veya gruplar arasında çatışmaya yol açan farklılıkları giderme çabası göstermektedir. Bu olgu, dün olduğu gibi bu gün de geçerliliğini korumaktadır. Bilgin (1998, s. 16) bu durumu şöyle örneklendirmektedir: "19.yüzyıl siyasal birliğini gerçekleştiren İtalya'nın karşısına çıkan ilk sorun, Mazzini'nin İtalya'yı yarattık; şimdi sıra İtalyanları yaratmakta" sözünde veciz bir şekilde ifade edildiği üzere, İtalyan ulus-devletini oluşturmak olmuştur. Bu anlayış, İtalyanlık'nn asla ezeli bir şey, bir öncel olmadığını; inşa edilecek, hayata geçirilecek bir şey olduğunu vurgulamaktadır. Özellikle Türkiye' nin uluslaşma süreci irdelenirken, 1920'lerin dil, eğitim, gelir, bölgeler arası refah düzeyi, köy ve kentlerin sosyo-ekonomik ve kültürel alt yapısı bugüne kıyasla dikkate değer ölçüde olumsuzdu.Bu bağlamda tüm olumsuzluklara rağmen dikkate değer başarılar elde edilmiş olup ulus-devlet ve cumhuriyet yurttaşlığı projesi bu bağlamda ele alınmalıdır. Bu söylemden olmak üzere Cumhuriyetin ulus oluşturma anlayışı bütünsel olarak ele alındığında, kültürel ve hukuki değerlerin öne çıktığı görülür. Bu noktada özellikle belirtilmesi gereken, meta-historik ve meta-kültürel düzeyde algılanan ulusal kimlik anlayışı, hukuksal anlamda, 'bir siyasal kimlik' olarak tanımlanan 'yurttaşlık' üzerine kurulmakla beraber, Kemalist çağdaşlaşma isteminin tanımlayıcı unsuru olan, 'politik-organik toplum' söylemine içsel/ dahil olarak düşünülmesi gerekmektedir. Özbudun'nun (1997) da farklı bir dil ve anlatımla vurguladığı gibi, toplumu politik-organik toplum olarak tanımlamak ve bu tanıma devlete sadakat ve siyasal yurttaşlık ilkelerini aşan bir epistemik ve normatif ayrıcalık ve öncülük vermek, ülke içinde çeşitli alt kimliklerin tanınmasına ve hukukça himaye edilmesine olanak vermemiş ve bu imkânı verebilecek, kamusal ve özel alan ayırımına dayalı liberal yurttaşlık anlayışını üretmemiştir". Meta-historik ve meta kültürel düzeylerde kurulan yurttaşlık anlayışı, Ögü̈n'ün de işaret ettiği gibi, kurulmaya çalışıla 'Cumhuriyet'in birleştirici kimliği olarak' hareket etmesi gereken "politik Türk kimliğidir” (Keyman, 1997). Bu kimlik anlayışı, politik-organik toplumun normatif öncülüğünü kabul ederek, ahlaki benlik konumunu 'çağdaşlaşma istemi ile özdeşleştirmiş' ve bu istemi temsil etmek için kendi bireyselliğini yaşamayı uzunca ertelemeyi temel görev olarak kabul eden bir yurttaşlık anlayışı, Türk politik kimliği anlayışını oluşturmuştur. Kemalist çağdaşlaşma isteminin yurttaş1; cumhuriyetçi, toplum için çalışan, modernite projesinin simgesi olan ulusdevlete karşı görevlerini yerine getirmeyi kendi siyasal ahlakı olarak gören, Plâtoncu 'erdemli yurttaşlık'tır. Osmanlı Devlet'inin yüzyılların ürünü çokuluslu, çok dilli ve çok kültürlü mozaiği üzerinde yeni bir "ulus" doğuyordu. Ancak bu yeni ulusun en belirgin özelliği, 'Misak-1 Milli' sinırları içerisinde yaşayan herkes, eşit hak ve ödevleri olan Türkiye dinsel bir aidiyete dayanmamasıdır. Tersine 'din' olgusu tamamen dışlanmıştır. Türk kimliği, geçmişle tüm bağlarını kırmak iradesinde olan devlet seçkinleri tarafından gerçekleştirilen siyasal bir inşadır. $\mathrm{Bu}$ doğrultuda, yurttaş, yeni resmi kimliğin ürünüdür. Kurtuluş Savaşı, yeni bir düzenin başlangıcının habercisi olarak kabul edilir. Yani: 'Hakimiyet-i Milliye'. Türkiye Cumhuriyeti 'ümmet'in yerine 'ulus'u, 'mümin'nin yerine 'yurttaş'1 getirirken, meşruluğunu gelenek ve dinden alan yönetim anlayışının 'tebaa'sı yerini 'yurttaş’a bırakmıştır. Dolayısıyla, geçmişin kulluk ve tebaalığı zor zanaat olarak ifade edilirken, Cumhuriyet'in yurttaşı doğal olarak merak konusudur. 
$\mathrm{Bu}$ konuyla ilgili olarak özellikle müfredat programlarının etkisi azımsanamaz. Türkiye'de erken Cumhuriyet döneminde yürürlükte olan müfredat programlarının özellikle Türkiye Tarihi, Türkiye Coğrafy6ası ve Malumat-1 Vataniye (sonradan Yurt Bilgisi) derslerine stratejik bir önem yüklemiştir. Örneğin ilk eğitimin amacı, yurttaş yetiştirmek, gençleri ait oldukları vatan ve ulusa uyumlarını sağlamaktır.

Yurt Bilgisi dersi de bu amacı doğrudan hedefleyen bir ders olup, bu itibarla diğer derslerin bir merkezini ve temelini oluşturur. Bu, "vatan ve millete intikal ettirmek" hedefi kurucu pedagogların okuldan bekledikleri sosyalleşme hedefinin sınırlarını da belitler (Üstel, 2004, 276). Aynı şekilde Hasan Ali Yücel'inde (1994, s. 227) ifade ettiği gibi, "Türk elitini hakiki Türk vatanperveri olarak yetiştirmek"tir. Malumat-1 Vataniye ve Yurt Bilgisi kitaplarında yer aldığ biçimiyle, okulda yurttaş eğitiminde çift yönlü bir hedef izlenmektedir. Bir başka anlatımla, erken Cumhuriyet'in istenen yurttaşı, bir yandan çağdaşlık/ medenilik bir yandan da yurttaşlık ve yurtseverlik ekseni üzerinde inşa edilmek istenmektedir. Amaç, uygar/ çağdaş ve yurtsever yurttaşın yaratılmasıdır. Bu amaç, "çağdaşlık ve yurtseverlik" temelinde biçimlenen Cumhuriyet Batıcılığının iradeci niteliği ile tamamen uyum gösterdiği görülmektedir. Dolayısıyla yurttaşlı̆̆ın, bireyin devlet karşısındaki hukuksal ve siyasal aidiyetinin ötesinde, belirli bir yaşam tarzı ve bu bağlamda da toplum projesini varsaydığını göstermesi açısından -çağdaşı̆̆ğ/ medeniliğiönemlidir. Örneğin 1940'lı yıllara kadar okutulan kitapların büyük bölümü yerlere tükürmemek, sokakta pijama ve gecelikle dolaşmamak, toplu taşıma araçlarında uyulması gereken kurallar gibi "istenen/ hedeflenen davranış kodlarının" empozesine ayrılmıştır. Bu durum, yurttaşın 'uygarlık/ çağdaşlık' yönünün oluşturulması ve sınırları son derece geniş bir şekilde tanımlanan 'kamusallık' anlayışının ortaya konması açısından değer taşımaktadır. Bir diğer anlatımla, yalnızca toplu yaşama ilişkin davranış kodlarının değil, aynı zamanda özel alana ilişkin davranış (görgü) kurallarının da en ince ayrıntılarına kadar belirlenmesi ve telkini söz konusudur.

Üstel (2004, s. 77), "sosyal sınıf tarafindan inşa edilmek istenen çağdaş/ medeni yurttaş profilinin 'yurttaş' cephesiyle ilgili temel özelliğini, hedeflenen yurttaşın niteliği açısından 'sivil' değil" ama Leca'nın (1996, s. 31) da tanımladığı biçimiyle "bütün aidiyet eksenleri üzerinde saltlıkla siteye aidiyet" alanında "militan yurttaş" olmasıdır.

Söz konusu edilen 'militan yurttaşlık' profili üç ana eksen üzerinde inşa edilir:

1) Yurtseverlik, 2) yurttaşlık hak ve yükümlülükleri, 3) tehlike ve düşman motifi. 'militan yurttaş'ın inşa edildiği yurtseverlik eksenine yakından bakıldığında, erken Cumhuriyet döneminde yurttaş profilinin, yurttaşlığın ön koşulu olarak yurtseverliği çıkardığını, bu yurtseverliğin ise, yalnızca teritoryal (ülkesel) sadakat ekseninde değil, aynı zamanda, kültürel ve etnik anlamda bir duyarlılık ve 'akrabalık' duygusuyla beslenen bir anlayış etrafında biçimlendiği görülmektedir.

İkinci nokta, yurttaşlığın donatıldığı hak ve görevler bütünüyle ilgilidir. Kırklı yılların sonuna kadar Yurt Bilgisi kitaplarının temel aktörü 'görevlerle yükümlü' yurttaştır, temel anlayış ise, 'yurttaşların hakları yükümlü oldukları görevlerin yerine getirilmesi için vardır' anlayışına dayanmaktadır. Yine Üstel (2004, s. 277), Mithat Sadullah'tan aktararak, 1934-35 tarihli Yurt Bilgisi'nde Türk yurttaşlarının görevlerini belirtir:

1) kendine karşı vazifelidir ki; sağlam vücutlu ve iyi huylu olmaktır.

2) Ailesine karşı vazifelidir ki; bu da ailesine sadık ve yardımcı olmaktır.

3) Köyüne, milletine karşı çalışkan ve olmaktır.

4) Vatanına hizmetlerini istekle ve sevinçle yapmaktır.

Militan yurttaşlık profilinin dayandığı üçüncü nokta ise, tehdit ve tehlike motifidir. Söz konusu tehdit ve tehlike temasının temel işlevi, 'öteki'nin işaret edilmesinden oluşan zihinsel bir seferberlik durumunu toplum üzerinde egemen kılmaktır. Bu anlayış çerçevesinde 1930'lu yıllara kadar tehdit motifinin, öncelikle padişah ve ailesi ile onlarla işbirliği yapan kişilerin şahsında somutlaştığını dolayısıyla da eski rejime dönme tehlikesinin satır aralarında da olsa varlığını sürdürdüğü görülmektedir. Bunun yanı sıra, reel düşman imgesinin yalnızca 'Yunanlılık'sınırlı tutulması da dikkat çekicidir.

Ders kitaplarında yurttaşın profili çizilirken, hukuksal alanda da Türkiye Cumhuriyet'i temelinde ilk yurttaşlık tanımı “1924 Teşkilat-1 Esasiye Kanunu'nun 88. maddesinde Türkiye' de 
yaşayan kişilerin din ve etnik kökenlerine bakılmaksızın Türk oldukları çerçevesinde yapılmıştır" (Somel, 1997, s. 79). Daha sonra 1928 yılında çıkarılan 1312 sayılı Türk Vatandaşlığı Kanunu, yurttaşlık düzenlemelerinin ayrıntılarının içermiştir. Bu kanun yurttaşlığı Osmanlıda olduğu gibi yine kan bağı kuralı ile değerlendirmiş, toprak bağı kuralı ancak çok sınırlı bir uygulama olarak kaydedilmiştir. Somel, bu gün geçerli olan 1964 tarihli ve 403 sayılı Vatandaşlık Kanunu'nun da aynı temel ilkeleri içerdiğini belirtir (1997, s. 81). Türkiye'de yurttaşlığı düzenleyen bu temel yasal belgedeki son önemli değişiklik 1981 yılında 'çifte vatandaşlık’ı mümkün kılan değişikliktir (13 Şubat 1981 tarih ve 2382 sayılı yasa). Küreselleşmenin içinde hızla yoğunlaşan uluslararası göçün sonucunda başka ülkelerde yaşamaya başlayan Türk yurttaşlarına bulundukları ülkenin yurttaşlık hakkını veren bazı düzenlemeler, İçduyu'nun (1996, s. 71) bir çalışmasında ifade ettiği gibi, "yurttaşlığın, bir ulusa üyelikten çok siyasal kurum olarak devlete üyeliği olduğu" anlamındaki felsefeyi içermektedir. Bu çerçeve de, en azından kuramsal düzeyde yurttaşlık kurumunun Türkiye' de geçirdiği dönüşümün son radikal noktasını oluşturur.

Cumhuriyet'in kuruluş döneminde 'çağdaşlık' ve 'uygarlık' iki temel unsur olarak ortaya çıkmıştır. Bu iki unsur açık olarak 'etkin ve militan' bir yurttaş tipini oluşturur. Cumhuriyet' in kurucuları "kimin ve nasıl Türk olacağı" temelindeki, çoğu kez dolaylı olarak sorulan bir soru ile yurttaşlık kurumunu inşa etmeye çalışmışlardır (Keyman ve İçduyu, 1998, s. 176).

Cumhuriyet'in yeni bir ulus yaratma, yeni bir kültür yaratma ve yeni bir yurttaş yaratma amaçlarının iç içe girmişliği, belirtilebilir. Temel olarak paylaşılan ortak ulusal kültür ve kimlik inşa etmek sağlam bir yurttaşlık kurumu oluşturmanın ön koşulu olarak algılanmıştır.

Bir ulusun inşa dönemini içeren bu yıllar içinde, Osmanlı ve İslam ile olan tarihsel bağlar mümkün olduğunca kesilmeye çalışılmış, yeni Cumhuriyet yalnızca ulusal ve seküler bir devletin yapılanmasına değil, diğer yandan da bu özelliklere uyum gösteren bir kültürel ve toplumsal yapının oluşmasına büyük önem vermiştir. Kemalist modernleşme projesi içinde, bu seküler devlet yapısının ve seküler toplumsal ve kültürel yapıların oluşumu neredeyse bir kültür devrimi, Mardin'in (1977, s. 209) deyimi ile "değerlerin devrimi" olarak belirtilmiştir. Temel alınan seküler değerler birey düzeyindeki yurttaş için de en belirgin ve belirleyici içsel özellik olarak düşünülmüş̧ür. Yeni bir yurttaşlık kavramsallaşması yapılırken, bu kavramsallaştırmanın temelinde ulusal kimlik, benzersiz, değişmez ve tarihle iliş̧kisi olan bir kimlik olarak tasarlanmış, son kertede de bu kimlik Türklük olarak tanımlanan tekil bir kültür üzerine ve diğer olası alt kimlikleri göz önüne almadan kurgulanmıştır. Bu çerçevede, kurgulanan kimlikle uyuşmayan, modernlik karşısında gelenekseli, evrensel karşısında yereli, Türk kimliği karşısında başka etnik ve ulusal kimlikleri temsil eden unsurların, kamusal alanın dışına itilmesi süreci yaşanmıştır. $\mathrm{Bu}$ süreç, yeni ulusun ve onun yurttaşlarının kolektif kişiliklerinin yeniden yapılandırılması anlamına gelen ve kamusal alanın yanı sıra birçok açıdan özel alanların da yeniden kurgulanmasını, geleneklerin ve göreneklerin bile gözden geçirilip, günlük özel yaşam biçimlerinin de "modernleştirilmesi”ni gündeme getirmiştir. Bu sürece paralel olarak, Türk kimliğinin yeniden yapılandırılması içinde Türklük kavramı bir verili 'biyolojik ya da kan bağı' ürünü olarak algılanmaktan daha çok, 'inşa edilen', yeniden üretilen bir kimlik olarak ortaya çıkmıştır.

Bu bakış açısından, "Balkanlarda Türk kökenli olmasa bile Türk kültürü ile yakınlıkları ve Müslüman olmaları nedeniyle birçok göçmenin ülkeye gelmesine ve yurttaş olmalarına izin verilmiştir, oysa örneğin, Türk olmalarına rağmen Hıristiyan Gagavuzların Türkiye'ye gelmelerine olanak sağlanamamıştır" (Somel,1997, s. 81). Benzer bir bakış açısıyla, Rumlar; Museviler ve Ermeniler gibi Müslüman olmayan azınlık kümelerine yalnızca yurttaşlık bazında Türk kimliği dillendirilmiş, ancak onlar hiçbir zaman inşa edilen Türk ulusunun doğal üyeleri olarak görülmemişlerdir. Yurttaşlık kurumunun inşasında egemen toplumsal ve siyasal zihin paralelinde "Türk olmak Müslüman olmakla özdeşleştirilmiş, gayrimüslimler ulus tanımının dışında algılanmışlardır" (Yumul, 1998, s. 145). Türk kimliği içinde İslam unsurunun en az etnik Türk kökeni kadar önemli algılandığı görülmektedir. Bu nokta yeni Cumhuriyet'in yeni bir ulus, yeni bir yurttaşlık kimliği inşasında karşılaştığı paradoks ortaya çıkar: Bir yanda, Osmanlıdan miras kalan millet sisteminin yansıması içinde, Müslüman olmayan unsurların yeni kurgulanan kimlik içerisinde ne şekilde yer alacakları, öte yandan "Müslümanlık" kimliğinin bu yeni kimliğe 
eklemlenme biçiminin ne olacağıdır. Yeni kimlik, her iki soruya da daha çok dışlayıcı bir bakışla yaklaşıldığı hissedilmektedir (Keman ve İçduyu, 1998, s. 177).

1950'lere kadar betimlenmeye çalışılan çerçevede, yurttaşlık kavramı Kemalist seküler bir Türk kimliği kavramı temelinde, türdeş ve seküler bir ulusal kültür şemsiyesi altında siyasal ve kültürel olarak tanımlanmıştır. Yani, yurttaş ve devlet ilişkisi içinde edilgen, ancak ulusun üyesi olarak ulusal idealleri taşıyan, aktaran ve yaşayan bir birey olarak etken bir yurttaş tipi ortaya konmuştur.

Cumhuriyet'in ellili yıllara kadar uzanan resmi yurttaş profili, özel alan ila kamusal alan arasında ayırımın yokluğu anlamında "holistik" yani "bütüncül" bir yurttaş anlayışına dayanmaktadır. Bu yurttaşlığın temelinde kültürel bir aidiyet duygusu yatmaktadır. Söz konusu yurttaş, refleksleri açısından 'sivil' değil, ama 'militan' yurttaştır. Yurttaşlar arasındaki sosyal bağların belirli bir 'iyi yaşam' anlayışına ve ortak yararı paylaşmaya dayanması nedeniyle 'toplulukçu' bir yurttaşlıktır. 'Devletleştirilen' bu yurttaşlık, kurum ve kurallarla ve bürokratik ulusçulukla uyum içinde yaşama anlamında apolitiktir. Zira devlet tarafından kurgulanan kamusal alan, nötr ve steril bir alandır. Bu arada daha öncede vurgulandığı gibi kırklı yılların sonuna kadar siyasal liberalizme kapalı olması nedeniyle sözü edilen yurttaşlığı 'katılımcı' boyutu eksiktir. Yani, siyasal katılım, yurttaşın devlete karşı 'yükümlülükleri/ borçları' bağlamında tanımlanan seçme-seçilme etkinliğine indirgenen bir görünüm sergilemektedir. Siyasal anlamda katılımcıllk, kişisel yararını toplumun genel yararıyla bütünüyle özdeşleştirmekle ifadesini bulan sosyal dayanışma motifi ile yer değiştirmiştir. Sosyal tutunum/birliktelik katılımla değil, ama dayanışmayla sağlanmak istenmiştir. Çok partili döneme geçiş, 1950'li yıllarla birlikte Türk kimliğinin resmi tanımlanışı üzerine dolaylı ve dolaysız tartışmalara yol açmıştır. Bu tartışmalar, erken Cumhuriyet döneminin yaklaşımlarına bazı belirgin değişiklikler ve dönüşümler de getirmiştir. Bu dönemde, Demokrat Parti'nin politikaları ile doğru orantılı olarak İslam unsurunun, gelenekselin ve yerelin siyasi olarak yeniden kurgulanan ulus ve yurttaş kimlikleri içine eklemlendiği görülmektedir. Bu anlamda, bu yıllar yeni Cumhuriyet'in ideolojik kurgularla gerilere, özel, kişisel alanlara itmeye çalıştığı geleneksel kimliklerin yeniden kamusal kimlikler olarak ifade bulduğu yılları içermektedir. Bu, yurttaşlıkla ilgili merkez-çevre çelişkisinin, çevre adına yeni bir açılıma gitmesi anlamını da taşımaktadır (Keyman ve İçduyu, 1998, s. 178). Geleneksel, yerel ve dinsel kimliklerin ulusal kimlik içindeki yeri ve öneminin artması bu dönemde başlamış olsa da, bu etki, 1980'ler sonrasındaki yükselişi öncesinde, 1960 ve 70'lerde daha sınırlı kaldığı gözlemlenmiştir. 1960 askeri müdahalesinden sonra yapılan yeni anayasa, seküler olduğu kadar toplumsal sivil ve katılımcı özellikleri de öne çıkan bir yurttaşlık kavramını ve anlayışını gündeme getirmiştir. Böylece 1960 sonrası dönem, devlet önünde edilgen olmaktan daha çok, toplumsal ve siyasal olarak etken bir yurttaş tipini daha da öne çıkarmıştır. Ancak, değeri vurgulanan bu etkenlik ve katılımcılık unsurlarının, çoğunlukla, yurttaşın "oy veren, askerlik yapan, vergi veren birey" konumu ile sınırlı olarak algılandığı da ifade edilmektedir. 1980 askeri müdahalesini izleyen dönem, yeni 1982 Anayasası temelinde, Kemalist yurttaşlık söyleminin, tarihsel ve moral değerlere dayalı Türk kimliğine "seküler bir İslam" unsurunu da eklenerek yeniden canlanmasını sağlayan oluşumlara olanak sağlamıştır. Öncelikle, "okulda yurttaş eğitimi”" 1980 askeri müdahalesiyle yeni bir evreye girmiştir. 1985 yılında Talim ve Terbiye Kurulu'nun aldığı bir kararla Ortaokullarda Sosyal Bilgiler başlığı altında okutulan dersin Milli Tarih, Milli Coğrafya ve Vatandaşlık Bilgileri adları altında üç ayrı ders olarak okutulmasına karar verilmiş̧tir. Bu değişiklik basit bir ad değişikliğinin ötesinde aslında bir zihniyet değişikliğinin, yeni bir zihniyet anlayışının/egemenliğinin habercisidir. Nitekim 1980'li yıllardan başlayarak İslamiyet'le de güçlendirilmiş bir kültürel yurttaşlığa geri dönüş söz konusudur. Vatandaşlık Bilgileri kitaplarında "ulusu oluşturan maddi unsurlara 'dil' ve 'ırk'ın yanı sıra 'din' unsurunun da eklenmesi, 'biz-onlar' şeklinde özetlenebilen 'özcükültürel yurttaşlık' anlayışının çerçevesini de belirler” (Üstel, 2002, s. 282).Başka bir anlatımla "din birliğinin olması, bireylerin birbirlerini sevmelerinde, yardımlaşmalarında, kaynaşmalarında etkili olur. Onun için, milletin meydana gelmesinde din birliğinin korunması önemlidir. Aynı dine mensup olmak, bireylerin birbirlerine karşı hoşgörülü olmalarını da gerektirir" (Aydos ve Yenice, 1994, s. 60), ya da "din kuralları toplumda bireylerin birlik ve beraberlik içerisinde yaşamalarını 
sağlayan harçtır" (Aydos ve Yenice, 1994, s. 21), anlayış1 doğrultusunda toplumsal tutunum/ birliktelik eksenini İslamiyet'e odaklayan bir anlayış ön plana çıkmıștır. Dolayısıyla 1980'li yıllarla birlikte, erken Cumhuriyet'in kültürel yurttaşlığının, din bağının da eklemlenmesiyle tahkimi görülmüştür. Yurttaşlık eğitimindeki bu zihinsel değişim, bir anlamda, Kemalist modernleşme projesinin yeniden gözden geçirilip, yeniden gündeme getirildiği dönemdir. Kemalizm'i bu gün ülkenin içinde bulunduğu sosyal, kültürel, ekonomik ve siyasal sorunların 'neden'i olarak görme alışkanlığı ve kolaycılığının temeli bu zihniyet değişikliği ile atılmıştır. Burada dikkat çekici olan ise bu değişim ve dönüşümlerin hepsi de 'Atatürkçülük ya da Kemalizm' adına yapılması gibi bir paradoksu da içinde barındırmadır.

\section{Küreselleşme ve Yurttaşlık Kavramının Dönüşümü}

Milli Eğitim Bakanlığı TTKB (2005) sosyal Bilgiler dersinin yeniden yapılandırılması çalışmasında evrensel amaçlar başlığı altında yurttaş yetiştirme konusunda 'ulusal kimlik, anayasal miras, yurttaşlık değerleri, haklar ve sorumluluklar ' başlığı altında 'küresel değerleri özümseyen yurttaş yetiştirmeyi’ de amaçları içerisine almıştır. Küreselleşmenin etkisi ve uzantısı yurttaşlık kavramının da sorgulanmasını hızlandırmıştır.

Küreselleşme süreçleri içinde artan toplumsal hareketliliğin yurttaş, ulus-devlet ilişkisi üzerindeki etkileri belirgin bir şekilde hissedilen radikal değişim ve dönüşümlerin yaşanmasına ya da yoğun olarak her düzeyde tartışılmasına neden olmuştur. Bu "değişim ve dönüşümler modernite projesinin krizi olarak algılanmakta ve ulusal kalkınmacılığın politika olarak terk edilmesini gündeme getirmekte ve modernleşme tarihinin eleştirisinin anti modernist ideolojilerin tekeline geçmesini ortaya çıkarmaktadır" (Keyman ve İçduyu, 1998, s. 180). Yani, Kemalist çağdaşlaşma istemi, modernitenin tek ve ayrıcalıklı olma konumlarını tartışılır hale getirmeye başlamıştır. Dolayısıyla, "modernite, kültürel kimlik, demokrasi ve insancıllık gibi sorularla ilgili, dünyaya ve İslami, ahlaki düzene açık, geniş tartışmanın yapıldığı" bir dönem yaşanmaya başlamıştır.

Kısaca küreselleşme kavramını ele alırsak, Küreselleşmenin siyaset, ekonomi ve kültür gibi kurumlara etki eden, çok boyutlu toplumsal sonuçları olduğu açıktır. $\mathrm{Bu}$ nedenle, küreselleşme çalışmalarını tek bir disiplinle açıklamak doğru bir yaklaşım olamaz. Tüm dünyaya yayılan Amerikan merkezli kitle kültürü, dünyanın dört bir yanında insanların tüketim alışkanlıklarını değiştirmekte ve dolayısıyla geleneksel ve yerel tüketim alışkanlıklarını değiştirmekte ve bu alışkanlıklar bu durumdan etkilenmektedir. Yine, ekonomik küreselleşmenin ve siyasal liberalleşmenin, ulus-devletlerde iktidarda bulunan siyasi partilerin politikalarını uygulamasını olanaksız hale getirmesi, bunun sonucunda da, bireylerin siyasete ilişkin eğilimlerini azalarak kültürel anlam arayışlarına yönelmektedirler. Yeni sosyal hareketlerle birlikte yeni kabileci eğilimlerin ve yeni kimlik politikalarının yükselişi bu yönelişlerin ürünüdür. Küreselleşme', oldukça yeni olarak kabul edilmektedir. İlk olarak 1960'larda ortaya çıkan küreselleşme kavramı, 1980'li yılların başında sıkça kullanılmaya başlanmıştır. Küreselleşmeyi, "hem dünyanın küçülmesi hem de bir bütün olarak dünya bilincinin güçlenmesi" olarak tanımlayan Robertson'un (1999, s. 21) yanı sıra Hall'da küreselleşmeyi “bir dünya süreci” olarak tanımlayıp (1998, s. 38), kavramın tarihsel bir zorunluluk içerdiğine işaret ederler. Giddens ise, küreselleşmeyi, "uzak yerleşimleri birbirine, yerel oluşumların millerce ötedeki olaylarla biçimlendirildiği ya da bunun tam tersinin söz konusu olduğu yollarla bağlayan dünya çapındaki toplumsal ilişkilerin yoğunlaşması" olarak tanımlar (1997, s.66). Harvey'de küreselleşmenin bir "zaman mekan" sıkışması olduğunu ve bu sıkışma sonucunda, dünyaya bakış tarzımızdaki değişikliğe vurgu yapar (1999, s. 270). Burada kullanılan sıkışma terimi ile 'yaşamın hızının artışı'nı ve 'mekân engellerinin aşınması'nın ifade edildiğini görmekteyiz.

1960'lı yıllarda McLuhan, elektronik iletişim alanındaki bu gelişmeler sonucunda dünyanın “küresel bir köy”e dönüştüğünü belirtecektir (2001, s. 44). Morley ve Robins, Harvey’in 'zaman ve mekan sıkışması' tanımına ilave olarak, bu 'sıkışma' sonucu küreselleşmeyi "anlık ve derinliği olmayan bir dünyanın yaratılması" olarak tanımlar (1997, s. 160). İletişim alanındaki bu hızlı değişim sonucunda dünya, üzerinde sınırların kalktığı, anlam mekânlarının sabitliklerini kaybettiği ve hemen hemen her şeyin akış halinde olduğu bir mekânın- mekânsızlığın yaşandığı 
yer haline dönüşmüştür. Diğer bir ifade ile "küresel uzam bir akışlar uzamıdır, merkezi yoktur, sınırların ve cephelerin nüfuz edebilir olduğu bir uzamdır. Bu küresel alanda ekonomiler ve kültürler birbirleriyle, her bir 'öteki' ile yoğun doğrudan bir ilişkiler içine firlatılıp atılırlar" (Morley ve Robins,1997, s. 160). Küreselleşmeyle birlikte uzak yerleşimler ve yerellikler birbirine bağlanmış olmaktadır yani etkileşim karşlıklıdır; küreselleşme yerelleşmeyi de doğurmaktadır, hem etkilemekte hem de ondan etkilenmektedir: "Küreselleşme diyalektik bir süreçtir; çünkü bu tür yerel oluşumlar, onları biçimlendiren çok uzak ilişkilerin tam tersi bir doğrultuya da yönelebilirler. Yerel dönüşüm, toplumsal bağlantıların zaman v uzam üzerinde yanlamasına genişlemenin bir parçası olduğu için küreselleşmenin de bir parçasıdır (Giddens, 1997, s. 66). Kızılçelik, "günümüzde herkesin dilinden düşmeyen küreselleşmenin özellikle anlamına tam uygun olarak kullanılmasa da, içeriğine ilişkin çeşitli argümanlar ileri sürülmesine ve bizatihi kendisi bir sorunsal olarak tartışılmasına karşın ne'liğinin netleştirilemediğini belirtir" (2003, s. 3). Bunun nedeni olarak da küreselleşme ile birlikte aynı zamanda, yenidünya düzeni, postmodernizm, yerelleşme ve neo-liberalizm gibi anlayışların entelektüel alanda tartışılmaya başlamasını göstermektedir. Ayrıca günümüz entelektüellerini bir kısmının söz konusu anlayış ve söylemleri birlikte düşünmek ten çok onları sanki birbirinden farklıymış gibi ele aldıklarını ve bu durumunda onların temel yanılgılarını oluşturduklarını belirtir. Kongar (2001, s. 37-40), küreselleşmenin üç kaynağına işaret etmektedir ve bu üç kaynak ise, siyasal, ekonomik ve kültürel şeklinde ifade edilmektedir.

Küreselleşmenin ulus-devlet ilişkisi içerisinde 'demokrasi' bağlamında ele alındığı ve özellikle de bireyin siyasal-demokratik haklarını irdeleyen çalışmalar oldukça yaygınlaşmıştır. Küreselleşme ve ulus-devlet tartışmalarının sadece devletle sınırlı olmadığ 1 , aynı zamanda yurttaşın konumunu da tartışmaya açtığı bilinmektedir. "Siyaset ve onun aktörü birey etkisizleştirilmekte, anlam kaybına uğramakta ve işlevsizleştirilerek neredeyse siyasetin reddedildiği 'politika karşıtı' olarak nitelendirebileceğimiz bir çağa doğru yol almaktayız" (Schedler; 197, s. 1). Devlete yönelik eleştiriler devlet kavramının var olduğu andan itibaren söz konusu olmakla beraber devlet ve siyaseti birbirinden ayrı tutmak gereklidir. Örneğin devleti bir kurum olarak ortadan kaldırabilirsiniz ancak bireyin, toplumsal grupların geleceği ve kaderini belirlemede en etkin araç olan siyasetten vazgeçmek mümkün değildir. Bu gün küreselleşme ile genel olarak dünyayı ve insanlığın kaderini, her ülkede bireylerin geleceğini etkileyen birçok karar az ya da çok söz sahibi oldukları 'ulusal egemenlik' sınırları dışına kaymakta/ kaydırılmaktadır. Dolayısıyla bu kararlar karşısında ulusal sınırlar içerisinde anlamı olan yurttaşlık hakları da işlevini yitirmektedir. Çünkü küreselleşme diye bir şey vardır artık; ancak 'küresel yurttaşlık' diye bir hak söz konusu bile değildir. Buna karşın ulusal düzeyde yurttaşlık hakk1 en kutsal haklardan birisidir. Bu durumda yapılması gereken ulusal yurttaşlığın içini boşaltmak gereklidir. Küreselleşmenin temel işlevlerinden birisi de budur. Bu yaklaşımın savunucularından Gülalp, "demokrasi, ulusçuluk, refah devleti ve demokrasi birbirleri ile bağlantılı oldukları için ve bu bağı kuran ortak unsur bir ulus-devletteki yurttaşlık ilişkisi olduğu için, demokrasinin günümüzdeki geçerli biçimleri ulus-devlet yapısı ile sınırlıdır, buna karşılık günümüzde küreselleşme diye adlandırılan bir süreç sonucunda ulus-devlet zayıflamakta özellikle de yurttaşların refaha ilişkin yükümlülüklerini artık yerine getiremez duruma düşmektedir" (2005, s. 29). Bu durum karşısında ulus-devleti aşan bir siyasal örgütlenmenin gerekliliğine örneğin "global demokrasi"nin kurulabilmesine işaret etmektedirler. Bu duruma paralel olarak, bu demokrasi sorununun temelinde başka bir sorunun yattığını da ileri sürerler: Bu da ulus-devletin çeşitli açılardan egemenlik alanının daraldığıdır. Yani ulus-devletleri artık yurttaşları üzerinde mutlak egemenlik kuramamaktadır. Özellikle bu son konu yani ulusdevletin yurttaşları üzerindeki mutlak egemenliği aslında biraz daha karmaşık bir konuyu içerir; yani, demokratik olsun ya da olmasın, ulus-devlet modelinin temel ilkesi şudur: Her ulus-devlet kendi sınırları içerisinde yaşayan insanlardan sorumludur ve onlar üzerinde egemenlik hakları taşır. Bu karşılıklı hak ve yükümlülükler çerçevesinde 'gönüllülük' esasını da içermektedir. Çünkü yurttaşın devleti aynı zamanda devletin de yurttaşıdır. İnsanlar kendi devletlerinin yasalarına göre yaşarlar. Bu bağlamda, geleneksel uluslararası hukuk da egemen devletlerarasındaki ilişkiler düzenlemekle yükümlüdür. Bu hukuka göre, devletler birbirlerinin iç işlerine karışamazlar ancak birbirlerini 
muhatap alırlar. İşte küreselleşme süreci ile birlikte günümüzde bu egemenlik hakları da sınırlıdır. Bunun özellikle demokratik olmayan ülkelerde olumsuz sonuçlara yol açtı̆̆ını ifade etmektedirler. Yani yurttaşlarına eskisi gibi hükmedemeyeceklerini belirtmektedirler. Burada ortaya çıkan ikilem şudur: Bir yanda küreselleşme süreci sonunda refah devleti zayıflayıp demokratik katılım sürecini zorlarken diğer yandan yine küreselleşme sonucunda ulus-devletlerin egemenlik alanları daralmakta ve bireyler kendi egemen devletleri karşısında uluslararası kuruluşları harekete geçirebilmektedirler. $\mathrm{Bu}$ durumun 'demokrasi' ile açıklanması ve demokrasinin lehine mi aleyhine mi? bir durum olduğu kestirilememektedir.

Tüm bu tartışmaların ışığı alında yurttaşlık kavramı da zamanın ruhuna uygun olarak değişmekte ve dönüşmektedir. Küresel yurttaşlık olarak özetlenen ancak her ülkenin /devletin sosyal, kültürel, ekonomik kalkınmışlığına paralel olarak içeriksel olmasa da anlamlandırma olarak değişmekte ve dönüşmektedir.

Tablo 1 ve Tablo 2'de görüldügü üzere özellikle son y1llarda "çifte yurttaşlık", “çoklu yurttaşlık", "dünya yurttaşlığı”, "Avrupa yurttaşlığı” ve "kent yurttaşlığı” gibi yeni kavramlar gündeme gelmektedir. "Günümüzde artık, ulusal nitelikli yurttaşlık anlayışından çoğul yurttaşlık anlayışına, bir diğer deyişle kozmopolitan yurttaşlık, diyasporik yurttaşlık, radikal demokratik yurttaşl1k, ulus-ötesi yurttaşlık, ekolojik yurttaşlık, radikal demokratik yurttaşlık gibi yeni açılımlara doğru yol alındığına tanık olmaktayız" (Kaya, 2006, s. 98). Bu değişim haklar ile milliyet arasında ya da yurttaşlık ile milliyet arasında bir ayrışmaya yol açmaktadır. $\mathrm{Bu}$ ayrışmanın en somut örneklerinden biri “AB yurttaşlığı”dır. AB yurttaşlığı bir ulus-üstü yurttaşlık biçimidir. AB yurttaşlığının ortaya çıkışı, "kozmopolit demokrasi”, "kozmopolitan yurtaşlık” ve "dünya yurttaşlığı" tartışmalarına bir ivme getirmiştir (Kastoryano, 2007, s. 36; Gülalp, 2007a, 17; Gülalp, 2007b, s. 179).

Tablo 1. Modern Vatandaşlık Kavramının Sorgulanması Sürecinde Önerilen Farklı Vatandaşlık Türleri*

\begin{tabular}{|c|c|c|c|}
\hline & $\begin{array}{c}\text { Katılım koşulları ve } \\
\text { vatandaşlık hakkı elde } \\
\text { edilmesi }\end{array}$ & $\begin{array}{l}\text { Hedef kimlik ve grup } \\
\text { aidiyeti }\end{array}$ & $\begin{array}{c}\text { Dişlama ya da } \\
\text { dişlanma durumu }\end{array}$ \\
\hline $\begin{array}{l}\text { Anayasal } \\
\text { Vatandaşlık }\end{array}$ & $\begin{array}{l}\text { Anayasanın hak tanıdığı } \\
\text { topluluğa üye olmak }\end{array}$ & $\begin{array}{c}\text { Topluluğun tarihi } \\
\text { olarak farklı grup ve } \\
\text { kimliklere sahip olması }\end{array}$ & $\begin{array}{c}\text { Anayasanın belirlediği } \\
\text { ölçütlerin dışarısında } \\
\text { kalmak, bırakılmak }\end{array}$ \\
\hline $\begin{array}{l}\text { Çok Kültürlü } \\
\text { Vatandaşlık }\end{array}$ & $\begin{array}{l}\text { Kültürel farklılıklar kabul } \\
\text { edilerek vatandaşlık hakkı } \\
\text { verilmesi }\end{array}$ & $\begin{array}{c}\text { Nüfus hareketleri } \\
\text { sonucu yan yana gelen } \\
\text { farklı kültürlerin } \\
\text { uzlaştırılması }\end{array}$ & $\begin{array}{l}\text { Kültürel tanınmanın } \\
\text { olmaması, ya da } \\
\text { tanınan kültürel } \\
\text { grupların dışlayıcılığı }\end{array}$ \\
\hline $\begin{array}{l}\text { Vatandaş Olmadan } \\
\text { Yerleşme Hakkı } \\
\text { veya Ulus Sonrası } \\
\text { (post national) } \\
\text { Vatandaşlık }\end{array}$ & $\begin{array}{l}\text { İkamet izni sayesinde } \\
\text { göçmenlerin vatandaş } \\
\text { olmadan da o devletin } \\
\text { vatandaşların ile çok } \\
\text { benzeyen medeni ve sosyal } \\
\text { haklara sahip olmaları }\end{array}$ & $\begin{array}{l}\text { Vatandaşlık şartı } \\
\text { aranmaksızın belirli } \\
\text { haklar verilen } \\
\text { göçmenler }\end{array}$ & $\begin{array}{c}\text { Göçmenlerin siyasi } \\
\text { haklarının olmaması } \\
\text { sonucunda medeni ve } \\
\text { sosyal hakları } \\
\text { konusunda söz hakkına } \\
\text { sahip olmamaları } \\
\end{array}$ \\
\hline $\begin{array}{l}\text { Kozmopolit } \\
\text { Vatandaşlik }\end{array}$ & $\begin{array}{c}\text { Vatandaşlık haklarının } \\
\text { ulus üstü bir otorite } \\
\text { tarafından verilmesi veya } \\
\text { yerel aktörlerle müzakere } \\
\text { edilmesi } \\
\end{array}$ & $\begin{array}{c}\text { Grup aidiyetine } \\
\text { bakılmaksızın her birey }\end{array}$ & $\begin{array}{c}\text { Yerel aktörlerin } \\
\text { vatandaşlık haklarının } \\
\text { verileceği durumlarda } \\
\text { keyfi olabilmesi }\end{array}$ \\
\hline Esnek Vatandaşlık & $\begin{array}{c}\text { Yasal haklardan } \\
\text { yararlanabilecek ölçüde } \\
\text { ekonomik hayata katılmak }\end{array}$ & $\begin{array}{l}\text { Grup aidiyetlerinin } \\
\text { esnek olmas1 }\end{array}$ & $\begin{array}{l}\text { Ulus-devletlerin hak } \\
\text { sağlama konusunda } \\
\text { tekelinin devam etmesi }\end{array}$ \\
\hline AB Vatandaşlı̆̆ 1 & $\begin{array}{l}\text { AB üyesi ülkenin } \\
\text { vatandaşı olmak }\end{array}$ & $\mathrm{AB}$ ortak kültürü & $\begin{array}{c}\text { Ulus-devlerin hala } \\
\text { vatandaşlık üzerinde } \\
\text { iddialarının olması }\end{array}$ \\
\hline
\end{tabular}

* Kadirbeyoğlu ve Sümer (2014) temel alınarak yazar tarafindan derlenmişstir. 
Bir Kimlik İnşası Olarak Ulus-Devlet Yurttaşlığı ve Yurttaşlık Kavramının Dönüşümü

Tablo 2. Vatandaşlık Halleri ${ }^{*}$

\begin{tabular}{|c|c|c|c|}
\hline & $\begin{array}{c}\text { Kendi içinde (sade) } \\
\text { vatandaş }\end{array}$ & Fedakar vatandaş & Kendi için vatandaş \\
\hline Grup tanımı & $\begin{array}{l}\text { • Yoksullar ve } \\
\text { yoksunların } \\
\text { oluşturduğu grup, } \\
\text { etnik Türk olmayanları } \\
\text { da kapsayabilen } \\
\text { (vatandaşlığa bakış } \\
\text { açısından değil, } \\
\text { vatandaşlığı tecrübe } \\
\text { etme konusunda) }\end{array}$ & $\begin{array}{l}\text { - Yurttaşlık eğitimini } \\
\text { devletten alabilmiş } \\
\text { sosyo-ekonomik grup, } \\
\text { etnik Türkler ağırlıklı }\end{array}$ & $\begin{array}{l}\text { - Kentlik bilincini öne } \\
\text { çıkartanlar, bireysel ve } \\
\text { bireyci orta-üst sınıf grup, } \\
\text { millet vurgusu yapmayan ve } \\
\text { etnik Türk olmayanların da } \\
\text { genelde içinde bulunabildiği }\end{array}$ \\
\hline Ödevler & $\begin{array}{l}\text { •Mecburiyetten, } \\
\text { içselleştirmeden } \\
\text { devlete karşı } \\
\text { yükümlülüğünü yerine } \\
\text { getiren. } \\
\text { •Vatandaşlık } \\
\text { kurumuyla sadece } \\
\text { eğitim aracılığıyla } \\
\text { tanışan. } \\
\text { •Oy ve vergi eksenli } \\
\text { ödevleri olduğuna } \\
\text { inanan. } \\
\text { •Negatif Ödevler: } \\
\text { Zorlama veya } \\
\text { zorunluluktan yerine } \\
\text { getiren }\end{array}$ & $\begin{array}{l}\text {-Vatanın, milletin, } \\
\text { devletin vatandaşı olarak } \\
\text { ödevlerini yapan. } \\
\text {-Vatandaşlık bilinci } \\
\text { olaylar karşısında ortaya } \\
\text { çıkabilen. } \\
\text { •Oy vermek ve vergi } \\
\text { dışında da millete karşı } \\
\text { ödevleri de olduğunu } \\
\text { düşünen. } \\
\text {-Nötr Ödevler: Yerine } \\
\text { getirdiği ödevlerin } \\
\text { kendisine etkisinin } \\
\text { olmadığını gören. }\end{array}$ & $\begin{array}{l}\text { • Yaşadığı yere karşı } \\
\text { sorumlulukları diğer } \\
\text { ödevlerden daha öne } \\
\text { çıartan. } \\
\text { •Vatandaşlık bilinci gündelik } \\
\text { halk pratiklerinden alan. } \\
\text { •Ödevlerinin salt devlete karşı } \\
\text { değil, topluma karşı da } \\
\text { olduğuna inanan. } \\
\text { •Pozitif Ödevler: Yerine } \\
\text { getirdiği vatandaşlık } \\
\text { görevlerinin kendisine } \\
\text { olumlu katkısı olacağını } \\
\text { düşünen. }\end{array}$ \\
\hline Haklar & $\begin{array}{l}\text { - Halklar konusunda } \\
\text { bilgisiz. } \\
\text { - Hak arama konusunda } \\
\text { tedirgin, çekingen ve } \\
\text { isteksiz. } \\
\text { - Negatif Haklar: } \\
\text { Ödevler dişında ekstra } \\
\text { çaba ile ancak bazı } \\
\text { haklarından bazen } \\
\text { yararlanabilen. }\end{array}$ & $\begin{array}{l}\text { •Devletin onayladığı ve } \\
\text { olumladığı ölçüde } \\
\text { hakları olduğunu } \\
\text { düşünen. } \\
\text { • Mevcut hakları militanca } \\
\text { savunan ve gerektiğini } \\
\text { hissettiğinde hak talebini } \\
\text { karşılayabileceklere oy } \\
\text { vererek himaye umut } \\
\text { eden. } \\
\text { •Negatif/Nötr Haklar: } \\
\text { Haklarından } \\
\text { yararlanamadığında } \\
\text { eleştirilerini kişilere } \\
\text { yönelten, devletin olağan } \\
\text { işleyebildiğinde } \\
\text { haklarına sahip } \\
\text { olabileceğine inanan. }\end{array}$ & $\begin{array}{l}\text { • Bireysel düzeyde hakkını hep } \\
\text { arayan. } \\
\text { • Haklarını aramak için sivil } \\
\text { toplumun da uygun olduğunu } \\
\text { düşünen. } \\
\text { - Pozitif Haklar: Vatandaşlık } \\
\text { görevlerini yerine getiren ve } \\
\text { haklarını da ona uygun } \\
\text { şekilde her alanda } \\
\text { kullanabilen. }\end{array}$ \\
\hline Özgürlükler & $\begin{array}{l}\text { •Özgürlükler ile hak ve } \\
\text { ödevlerin arasında bir } \\
\text { ilişki görmeyen. } \\
\text { • Olaylar karşısında ve } \\
\text { haklarını kullanırken } \\
\text { dahi özgürlüğün devlet } \\
\text { ya da başka bir erk } \\
\text { tarafindan } \\
\text { bahşedildiğini } \\
\text { düşünen. }\end{array}$ & $\begin{array}{l}\text { •Ekonomik kısıtların } \\
\text { diğer alanlarda } \\
\text { özgürlüklerini } \\
\text { kullanmasına engel } \\
\text { olduğunu düşünen. } \\
\text { •Fazla özgürlük yanlısı } \\
\text { olmayan, daha sıkı ve net } \\
\text { bir devlet-vatandaş } \\
\text { ilişkisini benimseyen. }\end{array}$ & $\begin{array}{l}\text { •Özgürlüklerin ve hakların } \\
\text { toplum ve devlete karşı } \\
\text { ödevlerin yerine getirilmiş } \\
\text { olmasından ve de vatandaşlık } \\
\text { statüsünden dolayı olduğunu } \\
\text { düşünen. } \\
\text { •Özgürlük yanlısı, bireysel ve } \\
\text { bireyci özgürlük } \\
\text { kavramsallaştırması yapan, } \\
\text { kendi özgürlüğünün }\end{array}$ \\
\hline
\end{tabular}




\begin{tabular}{|c|c|c|}
\hline $\begin{array}{l}\text { - Başkalarının } \\
\text { durumunu irdeleyerek } \\
\text { özgürlüklerini ele } \\
\text { almayan. } \\
\text { • Negatif Özgürlükler: } \\
\text { Özgür ve vatandaş } \\
\text { olduğu için değil, } \\
\text { ihtiyaç ve gereklilik } \\
\text { durumunda sadece } \\
\text { kullanılan haklar ve } \\
\text { özgürlüklerden } \\
\text { bahseden. }\end{array}$ & $\begin{array}{l}\text { • Milletin durumunu ele } \\
\text { alarak özgürlüklerini } \\
\text { değerlendiren. } \\
\text { •Nötr Özgürlükler: } \\
\text { Mevcut özgürlükleri } \\
\text { kanıksayan veyahut fazla } \\
\text { bulan, millet ve devlet } \\
\text { ayrımını görmediği için } \\
\text { özgürlükler konusunda } \\
\text { pozitif ya da negatif } \\
\text { tutumu olmayan. }\end{array}$ & $\begin{array}{l}\text { başkasınınkinin bittiği yerde } \\
\text { başlayabileceğine inanan. } \\
\text { - Başka bireylerin ödevlerini } \\
\text { yerine getirmeden hak sahibi } \\
\text { olmaları karşısında } \\
\text { özgürlüğ̈u kısıtlanmış } \\
\text { hisseden. } \\
\text { •Pozitif Özgürlükler: } \\
\text { Vatandaşın getirdiği hakların } \\
\text { bireyde olumlu anlamda } \\
\text { özgürlükler yarattığını ve ona } \\
\text { göre yaşaması gerektiğini } \\
\text { söyleyen. }\end{array}$ \\
\hline
\end{tabular}

* Kadirbeyoğlu ve Sümer (2014) temel alınarak yazar tarafindan derlenmiştir.

\section{Sonuç ve Tartışma}

Genel olarak her toplum siyasal ve toplumsal düzenini ideolojik söylemler aracıllğı ile yeni kuşaklara aktarmak ve meşrulaştırmak amacındadır. Devlet de politik bir kurum olarak, varlığını ulusal kültürle eşitleyerek ulus-devletlerin kuruluş ilkelerini meşrulaştırarak gelecek kuşaklara aktarır. Yurttaşlık olgusu da bu meşrulaştırma işlevini yerine getiren bireylerin varlığının devlete olan aidiyetiyle oluşmaktadır. Yurttaşlık genel anlamıyla bir siyasal topluluğa aidiyetken kaynaklanan hak ve görevler bütünü olarak ifade edilir. Yurttaşlığın hak ve aidiyet boyutu genel hukuksal açıdan ifade edilirken, siyasal özellikle de sosyolojik boyutunu vurgulamak gereklidir. Çünkü yurttaşlık, salt devlet merkezli bir tanımlamanın ötesinde hem farklı çıkarların/ çatışmaların birbirleriyle hem de devletle olan mücadelesi sonucunda kazanılmıştır. Yurttaşlık, hem hukuksal eşitlik söylemi sayesinde hem de bireyleri toplumun eşit üyeleri haline getirme mücadelesi nedeniyle çeşitli hak ve taleplerin birbirleriyle çatıştı̆̆ uzlaşmaz zemin potansiyelini de içermektedir. Böylece yurttaşlık, toplumsal birlik ve bütünlük oluştururken aynı zamanda bu birlik ve bütünlügü zayıflatmada da önemli bir kavram olarak karşımıza çıkabilmektedir. Yurttaşlık kavramının bu çeliş̧kili anlamı sayesinde yurttaşlık hakları genişlemiş ve giderek daha fazla toplumsa kesim yurttaşlık haklarından yararlanmaya başlamıştır. Böylece yurttaşlık, antik Yunan'dan günümüze kadar çok çeşitli sosyal, siyasal, kültürel değişimlerin ve çatışmaların merkezinde yer almış ve evrensellik iddiası ile de sürekli genişleyen bir içerik kazanmıştır. Dolayısıyla yurttaşlık konusundaki tartışmalara son nokta hiçbir zaman konulamayacaktır.

Yurttaşlık, siyasal topluluğun üyesi olan, bu toplulukta kendisine sunulan hak ve görevlerle, yasal bir statü kazanan ve böylece belli bir ülkenin yurttaşı olan ve resmi bir üyelik kazanan, kamusal yaşama aktif olarak katılan, demokratik siyasal arenada özgürce seçebilen, yaptığı seçimlerle yeri geldiğinde iktidarlara direnme cesaretini gösteren ve bütün bu fonksiyonları içinde hiçbir sorumluluğu almaktan kaçınmayan bireyleri anlatmakta kullanılan, Batı modernliğinin belirleyici niteliği olarak kullanılan bir kavramdır.

Osmanlı İmparatorluğu'ndan Cumhuriyet'e, Cumhuriyet'in kuruluşundan günümüze kadar toplumsal yapımızdaki sosyal, kültürel, ekonomik ve siyasal değişimler ve dönüşümler, 'yurttaş' oluşturma ve yetiştirmeyle ilgili anlayışın da değişim ve dönüşümlere uğramasına neden olmuştur. Bu gün Türkiye Cumhuriyeti'nde kuldan tebaaya, tebaadan yurttaşa yurttaşlık olgusu ve kimlik sorunları tartışılmaktadır. Batı'da birkaç yüzyıla sığan toplumsal değişmenin ülkemizde zaman zaman kopuşlara uğramasına rağmen onlarca yıla sığdırılmaya çalışıldığı, 21. yüzyılın, toplumsal ve siyasal tarihini Türk insanının kulluktan yurttaşlığa yürüyüşünün mücadele tarihi olarak özetlemek olasıdır.

Türkiye evrensel olarak tanımlanmış bir modernleşme modelinin en başarılı örneğidir. Osmanlı İmparatorluğu dönemi reformlarından başlayıp çağdaş ulus-devletle en yetkin anlamına ulaşan modernleşme ve batılllaşma tarihi, modernleşmenin düşün insanlarınca üretilen teorileri doğrular niteliğe sahip olduğu ifade edilir. Türk modernleşmesi, bütün ilhamını Batı'dan almış, elitler tarafindan yönlendirilen, uyum ilkesine dayalı ve gerekli toplumsal kurumların inşasına yönelik başarılı bir süreç olarak kabul edilir. Türkiye özellikle eğitim, hukuk, toplumsal yaşam, 
sanat, mimari ve gündelik yaşamdaki Batı normlarını, kurumlarını başarıyla uyarlamıştır. Dikkat çekici olan ise Türkiye'nin Müslüman kimliği ile bu modernleşmeyi başararak pek çok Müslüman üçüncü dünya ülkelerine de ilham kaynağı, hatta model olmuştur. Bu bağlamda Türk modernleşmesi Mustafa Kemal Atatürk'ün ulusal kurtuluş savaşı ile başlattığı ve geleceğe hazırladığı laik, demokratik, sosyal, hukuk devleti olan Türkiye Cumhuriyeti Devleti'nin tarihidir. Emperyalizme karşı verilen ulusal kurtuluş savaşında kazanılan askeri başarının sosyal ve siyasal başarılarla taçlandırıldığı Cumhuriyet rejiminin temel ilkeleri ve felsefesini benimsemiş kulluk kültüründen kurtulmuş yurttaşlarında tarihidir.

Yurttaşlığın ulus, ulus-devlet ve ulusçulukla bağlantılı olarak birey, kimlik, demokrasi, hak vb. kavramlarla ayrıca ya da birlikte tanımlanmaya gereksinim duyulduğu açıktır. Bununla birlikte kavramın ortaya çıktığı, geliştiği ve gözlemlendiği toplumsal yapının da kavramın kapsadığ 1 içerik açısından büyük önemi vardır. Ulus, ulusçuluk, ulus-devlet kavramları oluştuğu toplumsal yapılar içerisinde yurttaşında anlam kazandığ 1 tarihsel bir gerçeklik ifade eder. $\mathrm{Bu}$ bağlamda Osmanlı İmparatorluğunun yıkılması sonucunda ulusal kurtuluş savaşı ile kazanılan bağımsızlık ve emperyalizme karşı kazanılan mücadele sonucunda kurulan Türkiye Cumhuriyeti Devleti için anılan kavramların önemi yadsınamaz. Türkiye Cumhuriyeti demokrasi, insan hakları, hukuk ve laik temeller üzerine kurulmuş olup bu harç tüm inkâr ve tahriplere rağmen tutmuş̧tur. Ulusal iradenin hâkim kılınması ve egemenliğin tanrısal bir kaynaktan alınıp ulusa mal edilmesi, laik düzene yönelişinde kesin bir dönemecidir.

Günümüzde küreselleşme süreciyle birlikte cumhuriyetin kazanımlarının demokrasi, insan hakları gibi kavramların gerekliliği ön plana çıkarılarak sosyal, kültürel, demokratik özelliklerin edinildiği ulus-devletin ve ulusal yurttaşlığının sorgulandığı bir süreç yaşanmaktadır. Yani ulus-devlet yurttaşlığında küresel yurttaşlığa doğru yurttaşlık olgusu sorgulanmaktadır. Toplumlar varlıkları sürdürebilmek için ‘öteki’ni hep üretmişlerdir. İlkel topluluklardan günümüz modern toplumlarına kadar ötekine egemen olma isteği sürmüştür. Aynı zamanda her toplum ulus olmak için ötekine karşı var olma savaşı vermiştir. Ulus-devlet, küreselleştirilen dünyada küreselleştirilen yurttaşa, ulusal yurttaşlığı korumak için bütün toplumsal kurumlarıyla mücadele vermek durumundadır. Türkiye' de yurttaşlık olgusu sorgulanırken, modern yurttaşlığın oluşumu, gelişimi, küreselleşme süreciyle önerilen alternatif yurttaşlık anlayışları, küreselleşmenin kendisiyle birlikte sorgulanmalıdır. Küreselleşmeyle yurttaş ve devlet arasındaki ilişkiler açısından devletin hâkim rolü önemsizleştirilerek yurttaşın rolü ise sivil toplum adlandırması ile belirginleştirilerek dönüşüme uğratılmakta ve ülke sınırları içerisinde ulus dışı bir kimlik inşa edilmeye çalışılmaktadır. Ulusal kimliğin bireyin kendini ifade etme aracı olarak görmekten vazgeçerek yurttaşları hayal edilen bir cennet, bir dünya yurttaşlığı -Kant'ın kullandığı dünya yurttaşlığı ile kastedilen kavram ile ilişkisi yoktur- bir başka deyişle küresel toplumun bireyi beklemektedir.

Küreselleşme, ulus-devletleri egemenlik paylaşımına ve ulus-devletin yurttaşlarını da küresel toplumun bireyleri olmaya davet eden sivil toplum tartışmalarını yoğunlaştırmaktadır. Uluslar üstü sivil toplum kuruluşları ve uluslar arası organizasyonlar devletlerin egemenliklerine hatta devlerin otoritelerin karşı meydan okuma konumunda dahi olabilmektedirler.

Ulus-devletlerin yurttaşları ile ilişkileri kendi iç hukukları aracılığı ile eşitlik ilkesine dayanılarak yürütülür. Bu rol uluslar için vazgeçilmez olan egemenlik ilkesinin bir gereğidir. Fakat uluslar arası hukuk da ulus-devletlerin devletlerarasındaki ilişkileri düzenlemesi açısında kabul edilir. Ancak uluslar üstü organizasyonların ulus-devletlerin egemenlik alanlarını ve iç hukuklarını küresel ilişkiler bağlamında daraltmayı amaçladıkları da bir gerçektir. Sermayenin hareketlerini engelleyebilecek en büyük merkezi otoriteye dayalı bürokratik yapılanmasını kurmuş ulusdevletlerdir. Türkiye gibi sosyal, siyasal ve hukuk alanında köklü geçmişi olan ülkeler için bu durumu halletmenin yolu genellikle istikrarsız hükümetlerle kurarak aşılır. Diğer bir deyişle dış sermayeye ihtiyaç duyan devletler yaratılarak ulusal sermaye dışa bağımlı hale getirilir. Küreselleştirilen dünyada, küreselleşmiş devletlerin amaçlarına uygun hale getirdikleri en önemli kavram 'etnisite'dir. Bu kavram özellikle 1980'li yıllardan sonra 1rki birliktelik anlamında kullanılmaktan din ve dil birlikteliğini öne çıkaran anlamları ağırlık kazanmıştır. Bunlar siyasal amaçlar açısında mikro-ulusçuluğun ve cemaatçiliğin alt yapısın oluşturan kavramlardır. 
Dünyanın toplumsal ilişkiler anlamında eskiye oranla küçüldüğüne vuru yapan küresellikle ilgili çalışmalar, küresel sürecin başlamasıyla birlikte ulusal kimlikleri oluşturan kültürel unsurların kendilerini artık yeniden tanımlamaya gereksinim duyduklarını, ulusların tek bir kimliğe sahip olmalarının mümkün olmadığını ileri sürerler. Yurttaş ve devlet arasındaki ilişki açısından, devletin hâkim rolünü önemsizleştirip, yurttaşı sivil toplum nitelemesi ile dönüşüme uğratılmakta ve ülke sınırları içinde ulus dışı bir kimlik inşa edilmeye başlanmaktadır.

Küreselleşme ile oluşturulan yeni şartlar, uluslardan farklılaşmış ve ondan bağımsızlaşmış yeni bir uluslar arası toplum anlayışının ortaya çıkışını belirleyen şartlar olarak değerlendirilir. İstenilen daha az devlet, daha özgür iletişim, daha serbest ticaret, daha açık siyasal ve kültürel sınırlardır. Bir yandan yerelleşme, teknolojisi unsuru nedeni ile yerel kültürleri deforme ettiği için küreselleşmenin yerel manevrası olarak algılanırken, öte yanda aynı unsur sayesinde yerel olana kendini ifade firsatı verdiği için küreselleşmenin alternatifi olarak algılanabilmektedir. Dolayısıyla etnik yapıların bu zeminde kendilerini ifade etmelerinin ve ulusal kimlikten ayrı olarak var oldukları mesajını vurgulamaları da kolaylaşmakta ve aslında küreselleştiricilerin arzusu da gerçekleşmektedir.

Din, ulusların, bireyin kendisine ve toplumuna bakan yüzü olması anlamında bir kimlik olup küreselleşmenin oluşturduğu kriz alanlarındandır. Mevcut bireysel ve kolektif kimliklerin dönüşmeye zorlanmasına eşlik eden kriz, yenilerini de üretir.

Küreselleşme; 1rk, din, bölge, cinsiyet vb. faktörlere bağlı yeni kimlik taleplerinin ortaya çıkmasına yol açmıştır. Özellikle yaşanılan bölgeye, etnisiteye ve dine dayalı kimliklerin inşası bu süreçte hızlanmıştır. Ayrılıkçı etnik yapılanmalar, dine dayalı devlet istekleri, cemaatler, tarikatlar kendi yaşam biçimlerini bu süreçte özellikle de demokrasinin bir gereği adı altı bir teorik zeminde yaratarak yoğunlaşmıştır. Son yıllarda ülkemizde devletin, sosyal devlet olma ilkesinin gereklerini yerine getiren kurumlarının yanında sivil toplum adı altın kurulan ancak devletin yapması gereken yardım ve dayanışma işlevini yerine getirerek 'paralel bir devlet' oluşturmayı amaçladıkları gözlemlenmektedir.

Küreselleşme süreci, ulus-devletin çözüldügü ya da sonunun geldiği varsayımından hareketle ulusal yurttaşlığa alternatif yeni yurttaşlık arayışları ortaya koymuştur. Çok kültürlü yurttaşlı, anayasal yurttaşlık, imtiyazlı yurttaşlık, AB yurttaşlığı gibi etnik ayırımcılık ve dinsel yaklaşımları temel alan alternatiflerin uygulanabilirlik zeminlerini yaratmaya çalışmaktadır.

Küreselleşme, yukarıda ulusların egemenlik haklarını uluslar arası kuruluşlara aşağıda ise, mikroulusçuluk aracılığı, yerel, farklı kültürlerin bağımsızlaşması ve özerkleşmesiyle ulus-devlet modelini ve onun taşıyıcısı olan ulusal yurttaşı erozyona uğrattığı görülmektedir. Küreselleşme insanların hangi sorunlarını çözüyor, Dünyada ne üretilecek, nerede üretilecek, ne kadar üretilecek ve en önemlisi kim üretecek/ tüketecek gibi soruların yanıtları da kendisindedir. Buradaki temel sorun karar verilen üretimin ne kadar adil dağıtılacağı, refahın nasıl bölüşüleceğidir. Küreselleşme buna yanıt veremiyor çünkü sermayenin/ refahın belli alanlarda, ülkelerde yoğunlaşması zaten belirlenmiş durumdadır. Yani küreselleşme üretimi çözmüş ancak paylaşımı çözümsüz bırakmıştır. Ulusal egemenliği tahrip ettiğinden dolayı da karşı çıkma mekanizmaları etkisizleşmiştir. Sadece bu soruların bile yanıtlarının ulus-devlet ve onun yurttaşının varlığının gerekliliğine işaret olarak algılanmalıdır.

Türkiye insanının yurttaşlaşma sürecini ideolojik, toplumsal, yasal, anayasal ve bireysel boyutlarıyla, ağırlıklı olarak ulus-devlet ekseninde tartışılır ancak laik demokratik Cumhuriyet'in aşılan yolları göz önüne alınmadan bu ekseni bir ikilem olarak sunmak yanlıştır. Bu nedenle Türkiye için geçerli olduğuna inandığımız modern yurttaş tanımını şu şekilde yapabiliriz: Anayasa'nın 'laik, demokratik ve sosyal bir hukuk devleti' olarak tanımladığı Türkiye Cumhuriyeti'nin uyruğu olarak, yasalarca tanınmış belirli haklara ve yükümlülüklere sahip, ancak yurttaşlı̆g siyasal planda sadece seçimlerde oy kullanmakla sınırlı kalmayan, soyut ve edilgen bir yurttaştan öte, siyasal, sosyal ve ekonomik alanlarda, anayasal ve yasal güvencelerden de yararlanarak, yönetenleri sorgulayıcı, denetleyici, ülke sorunlarını tartışan ve siyasal karar süreçlerini etkileyebilen, katılımcı, çoğulcu, kısacası hem yasal açıdan hem de zihniyet açısından etkin bir yurttaşlıktır. 
Bir Kimlik İnşası Olarak Ulus-Devlet Yurttaşlığı ve Yurttaşlık Kavramının Dönüşümü

\section{Kaynaklar}

Ağaoğulları, M. A. ve Köker, L. (2000). Kent devletinden imparatorluğa. Ankara: İmge Yayınevi. Arat, Y. (1998). Türkiye'de toplumsal cinsiyet ve vatandaşlık. 75. yılda Tebaa'dan Yurttaş'a Doğru. (s. 67-77). İstanbul: TETTV.

Baydur, M. (1998). Küreselleşme -Yerellik gerilimi ve kimlik dalgası. Türk Yurdu, 18(129), 14 17.

Bora, T. (1997). Türk sağının üç hilali. İstanbul: İletişim.

Bora, T. (1998). İnşa döneminde türk milli kimliği. Toplum ve Bilim, 71, 168-194.

Bilgin, N. (1998). Cumhuriyet fikri ve yurttaş kimliği. 75. yılda Tebaa'dan Yurttaş'a Doğru. (s. 139-151). İstanbul: TETTV.

Bilgin, N. (2005). Küreselleşme demokrasiyi zayıflatıyor mu? Sivil Toplum, 1, 25-33.

Borne, D. (1996). Fransız eğitim sisteminde tarih, coğrafya ve yurttaşlık bilgi tasarımı ve bu tasarımın yurttaş oluşumuna katkısı. T. Ilgaz (Yay. Haz), H. Tufan (Çev.) Dersimiz: Yurttaşlık içinde (157-167). İstanbul: Kesit Yayıncılık.

Desforges, L. ( 2004). The formation of global citizenship: "international non-governmental organization in britain". Political Geography, 23, 549-569.

Erol, N. (1997). Yurttaşlık ve demokrasi: çoğulcu bir yurttaşlık kavramına doğru. N. Bilgin (Yay. haz.) Cumhuriyet, Demokrasi ve Kimlik içinde (s. 119-129). İstanbul: Bağlam Yayınları.

Giddens, A. (1994). Modernliğin sonuçları. E. Kuş̧il (Çev.). İstanbul: Ayrıntı Yayınları.

Gülalp, H. (2001). Ulusal devlet, global demokrasi. Küreselleşme ve ulus-devlet. M. Koray (Yay. Haz.) İstanbul: YTÜ Stratejik Araştırmalar Merkezi.

Gülalp, H. (2007a). Milliyete karşı vatandaşl1k. H. Gülalp (Yay. haz.). Vatandaşlık ve Etnik Çatışma içinde (s. 11-34). İstanbul, Metis Yayınları.

Gülalp, H. (2007b). Ulus devlet aş11ıyor mu? H. Gülalp (Yay. haz.). Vatandaşlık ve Etnik Çatışma içinde (s. 11-34). İstanbul, Metis Yayınları.

Hall, S. (1998a). Yerel ve küresel: küreselleşme ve etniklik. kültür ve dünya sistemi. A. D. King (Yay. haz.), H. Yolsal ve G. Seçkin (Çev.). Ankara: Bilim Sanat Yayınları. 39-62.

Hall., S. (1998 b). Eski ve yeni kimlikler, eski ve yeni etniklikler. Kültür ve dünya sistemi. A. D. King (Yay. haz.), H. Yolsal ve G. Seçkin (Çev.). Ankara: Bilim Sanat Yayınları, 63-96.

Harvey, D. (1999). Postmodernliğin durumu. S. Sarvan (Çev.). İstanbul: Metis Yayınevi, 2. Bask1.

Kadirbeyoğlu, Z. ve Sümer, B. (2014). Ulus-Devletlerde vatandaşl1k ve kimlik. E. Balta (Yay. haz.). Küresel Siyasete Giriş: Uluslararası Illişkilerde Kavramlar, Teoriler, Süreçler içinde (s. 491-504). İstanbul: İletişim Yayınları.

Kastoryano, R. (2007). Alman birliğini yeniden tanımlamak; milliyetten vatandaşlığa. H. Gülalp (Yay. haz.), Vatandaşlık ve Etnik Çatışma içinde (s. 35-58). İstanbul, Metis Yayınları.

Kaya, A. (2006). Yurttaşlık, azınlıklar ve çokkültürlülük, H. Thomas ve T. B. Marshall (Yay. haz.). Yurttaşlık ve Toplumsal Sinıflar içinde (s. 95-142). İstanbul: İstanbul Bilgi Üniversitesi yayınları.

Keyman, E.F. (1997). Kemalizm ve modernite, gelenek. Toplum ve Bilim, 72, 63-76.

Kızılçelik, S. (2005). Atatürk'ü doğru anlamak. Ankara: Anı Yayıncılık,

Keyman, E. F ve Ahmet, İ. (1998). Türk modernlerşmesi ve ulusal kimlik sorunu; anayasal vatandaşlık ve demokratik açılım olasılığı. 75. Yılında Tebaa'dan Yurttaşa Doğru. (s. 169-180). İstanbul: TETTV.

Kızılçelik, S. ve Erjem, Y. (1992). Açıklamalı sosyoloji sözlüğü. Konya: Saray Kitabevleri.

Kızılçelik, S. (2002). Kapitalizmin diasporası olarak küreselleşme. Eğitim Araştırmaları, 6, 12 33.

Kongar, E. (2001). Küresel terör ve Türkiye, küreselleşme, Hungtington, 11 Eylül. İstanbul: Remzi Kitapevi.

Köker, L. (1997). Kimlik krizinden meşruluk krizine. Toplum ve Bilim, 71, 11-20.

Leca, J. (1996). Bireycilik ve yurttaşlık. Dersimiz yurttaşlık. E. Balibar ve D. Borne (Yay. haz.) İstanbul: Kesit Yay. 
Güngör

Marshal, T.H. ve Tom, B. (2000). Yurttaşlık ve toplumsal sınıflar. (Çev: Ayhan Kaya) Ankara: Gündoğan Yayınları.

MEB (2005). İlköğretim sosyal bilgiler dersi 6. ve 7. sinıf ögretim programı ve kılavuzu, Ankara, TTKB.

Morley, D. ve Robins, K. (1997). Kimlik mekânları. E. Zeybekoğlu (Çev.). İstanbul: Ayrıntı Yayınları.

Mouffe, C. (1992). Dimensions of radical democracy-pluralism, citizenship, community. C. Mouffe (Yay. haz.). (s. 225-239), Londra, New York.

Mardin, Ş. (1994). Türkiye'de Din ve Siyaset. İstanbul: İletişim

Özbudun, E. (1997). Milli Mücadele ve Cumhuriyetin Resmi Belgelerinde Yurttaşlık ve Kimlik. Cumhuriyet, Demokrasi ve Kimlik. İstanbul: Bağlam Yay.

Özkazanç, A. (1998). Türkiye'de sivil iktidar ve meşrutiyet sorunu: 1980'li yıllarda yeni sağ, (Yayınlanmamış doktora tezi), Ankara: Ankara Üniversitesi Sosyal Bilimler Enstitüsü.

Robertson, R. (1999). Küreselleşme; toplum kuramı ve küresel kültür. H. Yolsal ve G. Seçkin (Çev.). Anlara. Bilim ve Sanat Yayınları.

Sarıbay, A.Y. (1998). Siyasal sosyoloji, İstanbul: Der Yayınları.

Schedler, A. (1971). Introduction: antipolilitics-closing colonzing the public sphere. The End of Politics. A. Schedler (Yay. haz.) Great Britain: Macmillan Pres.

Somel, A. (1999). Osmanlı'dan cumhuriyete türk kimliği. Cumhuriyet, demokrasi ve kimlik. N. Bilgin (Yay. haz.) (s. 71-85). İstanbul: Bağlam Yay.

Timur, T. (1986). Osmanlı kimliği. İstanbul. Hil Yayınları.

Ünsal, A. (1998). 75. yllda tebaa'dan yurttaş'a doğru, İstanbul: TETTV

Üstel, F. (2004). Makbul vatandaşın peşinde: II. Meşrutiyet'ten bugüne vatandaşlık eğitimi. İstanbul İletişim Yayınları:

Üstel, F. (2001). II. Meşrutiyet ve vatandaşın “icad”1. Cumhuriyet'e devreden düşünce mirası. Tanzimat ve Meşrutiyet'in Birikimi. İstanbul: İletişim, 166-179.

Üstel, F. (1997). Türkiye Cumhuriyetinde resmi yurttaş profilinin evrimi. Cumhuriyet, demokrasi ve kimlik. İstanbul. Bağlam Yayınları, 128-154.

Varol, M. (1997). Kuramda ve gerçeklikte yurttaş. N. Bilgin (Yay. haz.) Cumhuriyet, Demokrasi ve Kimlik içinde (s. 31-39). İstanbul: Bağlam Yayınları.

Von Barloewen, K. (2001). Modernleşme ve küreselleşme sürecinde kültürel kimlik, küreselleşme ve modernleşme sürecinde kültürel kimlik. Ankara: Konrad Adenover Vakfı Yay, 1-13.

Yıldız, A. (2001). Kemalist milliyetçilik. İstanbul: İletişim Yay.

Yumul, A. (1998). Evrenselcilik ile yerelcilik arasında ırkçılığın dili. Foreign Policy, 1(1), 139161.

Yücel, H. A. (1994). Türkiye’de ortaöğretim. Ankara: Kültür Bakanlığı Milli Kütüphane Basımevi.

\section{Extended Abstract}

\section{Introduction}

As the foundation of the nation and the nationalization period progressed together in Turkey, the basic philosophy and the principles about the formation of the Turkish national citizenship form the basis for the understanding of citizenship concept. In this sense, the level, which the Turkish Republic Citizenship has reached today, has been examined by considering the social, economical and cultural effects of the globalization process on the nation-state. Nowadays the problems that nation-state citizenship faces cannot be isolated from the problems that the world faces. The social, political and economical crisis which capitalism, so called as globalization process, has made the existence of the nation-state questionable. Citizenship concept must be handled within this new world order. Along with the globalization process, nation-state citizenship loses its meaning. The citizenship concept has gained its modern content with the existence of the nationstate. As the social, political, economical and cultural changes and transitions in our world 
formed the conditions for the nation-state, the conditions for citizenship were being formed. The latest state model of the modern world is nation-state. The effects of the globalization process on nation-state's national sovereignty and national identity question the existence of the states. The basic principles of each nation-state, like independence and sovereignty, have lost their value with the effect of the globalization process. As a matter of course, Turkish Republic is affected with this process as well. The basic philosophy and the principles of the Republic are under threat. The changes in our social structure beginning from the Ottoman Empire to Republic, from the foundation of the Republic up to now also involve the existence of a new state and the understanding of the formation and bringing up 'new citizen'

\section{Method}

In this study, historical approach (Kızılçelik \& Erjem, 1992) and document analysis as a strategy were utilized to focus on the concept of citizenship covering the historical development / evolution of the notion till today.

\section{Results and Discussion}

States have shaped their existence socially, politically, economically, and culturally, and they provided their individual citizens with rights in this context. Nation-state is one of these models. The existence of Turkish Republic, as a whole, including its foundation, constitutions, and Ataturk's discourse, survives in respect to the Republic's founding principles promoting an understanding of Kant on one hand and the French revolution on the other. This understanding depends on the principles embodied in foundation of nation-states and Universal Declaration of Human Rights. Here, three characteristics play a deterministic role. Turkish Republic, having exercised the attempts of engaged citizenship of the Ottoman Empire, was founded with an ideal of being an individual part of the western civilization owning the rights and status of its individual citizens. This is the "activist citizenship" built on a state of belonging, but not on a state of being a civilian considering the expected quality targeted by the social class and its basic principles of citizenship. The profile of militant citizenship is centered around three basics. 1) Patriotism, 2) The rights and responsibilities of citizenship, 3) The motive of danger and hostility. The official citizenship profile of the Republic until 50s is based on a holistic view of citizenship which refers to non-existence of a classification of private and public spheres. This kind of citizenship emerges from a state of cultural belonging. The citizen in question here is not a civilian, but a militant.

This also means that the conflict of center-periphery goes through an expansion in favor of periphery. Although the importance of traditional, local, and religious identities was grown as a part of national identity in those years, it was seen limited in 1960s and 70s before its rise in 1980s. The new constitutional law, made after the 1960 coup, brought out the citizenship concept which came into prominence with its secular, public, civil, and participatory features. This period after 1960s created a type of citizen who is active socially and politically rather than passive in the state. Still, these elements of valued activeness and involvements are expressed to be perceived as limited as in a definition of an individual who votes, pays taxes, and performs military service.

The period following the military coup in 1980, paved the way for new formations which gave life to Turkish identity with an understanding of secular Islam based on 1982 constitutional law, Kemalist citizenship, and historical and moral values. First, "civics" was evolved. Social Studies course was divided by the Board of Education and Discipline into three different courses such as National History, National Geography, and Civics. This was a change and a messenger of a kind of dominance in mindset and mentality beyond a change in the name of the course. Likewise, a return to cultural citizenship empowered with Islam starting in 1980s was experienced. In Civics books, stating "the elements building a nation" were added "religion" beside "language" and "race" shaped the framework of self-cultural citizenship which can be summarized as "we-them".

The effects of social mobility driven by globalism on the relationship between the citizen and the nation-state caused radical changes and transformations or discussions of them. These 
changes and transformations were perceived as a crisis of modernism project, brought the idea abandoning the support of national development in politics, and made the criticisms of the history of modernism monopolized by anti-modernist ideologies. In fact, the concept of citizenship has been changing and transforming into a new being. Global citizenship has also been changing and transforming in meaning with social, cultural, and economical development of each state/country.

Especially in recent years, concepts like double citizenship, multi-citizenship, world citizenship, Europe citizenship, and urban citizenship have become current issues. We have been witnessing new formations such as plural citizenship, in other words, cosmopolitan citizenship, diasporic citizenship, radical democratic citizenship, post-national citizenship, ecological citizenship rather than national citizenship. This change causes separation between rights and nationality or citizenship and nationality. A concrete example of this separation is EU citizenship. EU citizenship is a kind of post-national citizenship. The emergence of EU citizenship caused discussions of cosmopolitan democracy, cosmopolitan citizenship, and world citizenship, and the forms of citizenship have been pluralized and become cyclical.

Nowadays, the conflicts of citizenship occur because the questions about the rights in citizenship and the responsibilities of states upon their citizens have not been yet answered, and there is a rapid change in socio-economic and cultural conditions. We can infer that, in the near future, the discussions will continue and social scientists will do more research and contribute these discussions on citizenship. These discussions focus on the assumption that the state is the main character in international relations, and it protects its benefits. In this regard, the change in the roles of factors brings out the proliferation of identity politics. This will cause discussions in the meaning of citizenship and the protection of citizens' benefits by the states in the international arena. This will make the nation-state citizen become the core issue of international relations. 